\title{
LAS CONDUCTAS SIMBÓLICAS EN EL PALEOLÍTICO. UN INTENTO DE COMPRENSIÓN Y ANÁLISIS DESDE EL ESTRUCTURALISMO FUNCIONAL
}

\author{
The symbolic behaviors in the Paleolithic. An attempt \\ at understanding and analysis since functional structuralism
}

\author{
Ángel Rivera ${ }^{1}$ \\ Mario Menéndez ${ }^{2}$
}

Recibido el 9 de mayo de 2012. Aceptado el 7 de agosto de 2012

Resumen. La capacidad de simbolización es un proceso evolutivo con diferentes etapas. La elaboración de un método psicobiológico de análisis y de un modelo interpretativo permite determinar los marcadores arqueológicos de este proceso y ordenarlos en el tiempo y en el espacio. Así, proponemos un desarrollo en fases a lo largo del Paleolítico europeo, con grandes diferencias regionales, hasta la extensión continental del modelo en su más alto grado durante el Gravetiense, con la aparición de los comportamientos religiosos generalizados.

Palabras clave: Paleolítico, simbolismo, lenguaje, arte, adornos, enterramientos, teriántropos.

Abstract. The human capacity of symbolization is an evolutionary process with different stages. The production of both a psychobiological method of analysis and an interpretive model allows determining the archaeological markers of this process as well as arranging them in the time and in the space. Thus, we propose a phased development over the European Palaeolithic, with broad regional differences, reaching the continental extension of the model at its higher degree during the Gravettian, with the appearance of widespread religious behaviours.

Key words: Palaeolithic, symbolism, language, art, ornaments, burials, mediators.

\section{INTRODUCCIÓN}

La reflexión sobre el origen y desarrollo de las conductas simbólicas humanas durante el Paleolítico ha estado condicionada por un prejuicio en la interpretación de los objetos sin utilidad práctica conocida o las manifestaciones que trascienden la estricta materialidad adornos, arte, enterramientos, territorialidad, adaptabilidad, lenguaje, etc.-', asociándolos automáticamente a comportamiento simbólico, religiosidad, etc., sin ninguna matización; vinculándolo además a una única especie, que por extensión hemos definido como humanos anatómicamente modernos -HAM-; todo lo más se ha otorgado el beneficio de la duda a los neandertales $-\mathrm{HN}-\mathrm{O}$ al menos, a una parte de ellos. Esta identificación del comportamiento simbólico con una especie y un origen puntual y abrupto, definidos ocasionalmente

(1) Hospital del Tajo. Aranjuez. Ldo. en medicina y Dr.en Prehistoria. arivera52@gmail.com

(2) Dpto. de Prehistoria y Arqueología. UNED. Profesor titular de Prehistoria.mmenendez@geo.uned.es

Agradecemos a David Alvargonzález, de la Universidad de Oviedo, y a Eugenia Ramirez, de la UNED, la lectura y crítica de este trabajo desde la perspectiva de la Filosofía de la Religión y la Antropología Cultural. Algunas de sus sugerencias, así como las de los evaluadores externos de ETF, están recogidas en el texto. Los errores y omisiones son exclusivamente de nuestra responsabilidad. 
como "episodios saltacionistas", relacionados con una mutación favorable (Klein 2003), o unas circunstancias extraordinarias, sin gradación o evolución, constituye un paradigma mayoritariamente abandonado, aunque se haya reformulado dentro de la interpretación darwinista, como una "emergencia de punto crítico" (Reid 2007). Sin embargo, mantiene el sustrato de exclusividad biológica y, sobre todo, simplifica en exceso un proceso mucho más complejo. Una variable que aún hoy no podemos más que intuir pero que, probablemente, enriquezca y complique el tema en el futuro es la existencia de especies humanas alternativas a las consideradas habitualmente en la horquilla temporal más importante de este trabajo, la que va de 50.000 a 25.000 BP, como sorprendentemente sugieren los restos humanos de Denisova o la Isla de Flores (Krause et al. 2010; Morwood et al. 2005).

La arqueología ha aportado nuevas y más fiables informaciones en los últimos años, pero no se ha dotado de una teoría que matice y analice los datos, ni ha reflexionado sobre sus propios intentos de conocimiento y sobre la escasa capacidad desde sí misma, en exclusiva, de abordar la cuestión en toda su complejidad. Por ello ha hecho frecuentemente una interpretación simplificadora de cada nuevo dato, incorporándolo a una teoría explicativa previa del proceso general, con conclusiones no falsables. Por tanto, parece necesario dotarse del método adecuado y desprenderse de prejuicios (Balari et al. 2010), definir claramente qué es lo que queremos estudiar, racionalizar el proceso y elaborar una teoría interdisciplinar de análisis. Se trataría de formular hipótesis explicativas a partir de los nuevos datos que diversas ciencias experimentales nos ofrecen, procurando que no entren en contradicción entre ellas ni con los datos fiables del registro arqueológico.

En los trabajos sobre la conducta simbólica del Paleolítico es frecuente estudiar sus diversas formas por separado (manifestaciones artísticas, conducta funeraria, lenguaje, etc.) con la finalidad de desarrollar cada tema con la mayor profundidad posible. Sin embargo, esta tendencia ofrece un aspecto de independencia cognitiva y conductual que no se corresponde con la realidad neurológica conocida en la actualidad. En el presente trabajo hemos intentado analizar el simbolismo como un proceso cognitivo único que presenta diversas manifestaciones conductuales rastreables en los datos arqueológicos, pero con una misma base común que une su origen y las características de su desarrollo. Este tratamiento general implica una cierta limitación expositiva, pero ofrece alternativamente una concepción global de la conducta simbólica en todas sus formas.

Tras una breve exposición de la actual Arqueología cognitiva, que asumimos como marco propio de reflexión, y de los problemas que existen en su desarrollo y aplicación, intentaremos exponer resumidamente una metodología de análisis interdisciplinar, que definimos como modelo psicobiológico, dentro de una teoría general interpretativa,

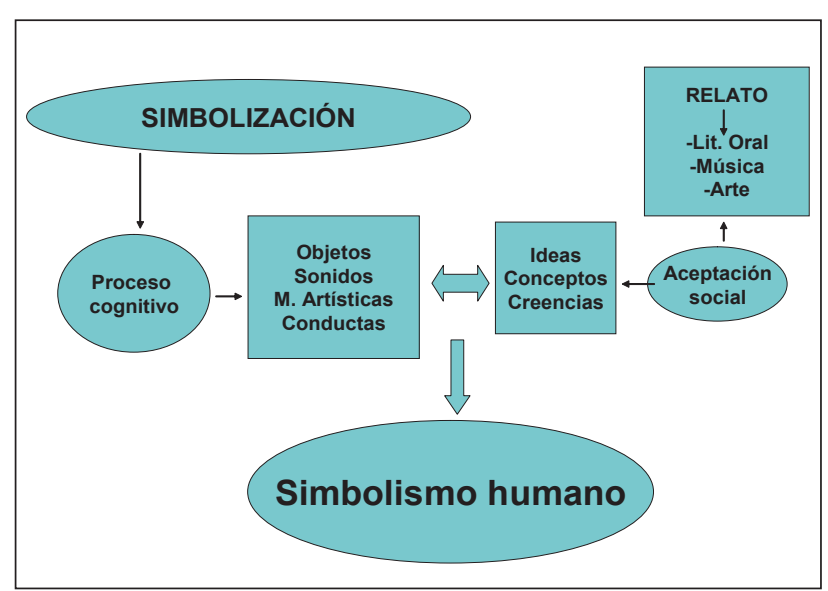

A CuAdro 1. Representación del concepto de simbolismo humano según se emplea en este trabajo.

el estructuralismo funcional. Nuestra diferente formación desde la arqueología prehistórica y la neuropsicología posibilitan la colaboración interdisciplinar que venimos manteniendo desde hace más de una década y nos facilitan la reflexión, desde un enfoque diferente al tradicional, sobre uno de los temas clave que nos define como humanos y nos permite proponer hipótesis sobre las fases de desarrollo de un largo y complejo proceso, siempre sujeto a los ajustes que la arqueología prehistórica, la paleogenética o cualquier otra ciencia puedan aportar al modelo de análisis o a sus conclusiones.

\section{UNA METODOLOGÍA PARA EL ANÁLISIS DEL SIMBOLISMO HUMANO}

Desde la arqueología prehistórica entendemos el simbolismo humano como el proceso cognitivo que otorga a determinados objetos, gestos, sonidos, manifestaciones artísticas o a ciertas conductas la representatividad de algunas ideas, conceptos o creencias que la sociedad ha creado y aceptado en su conjunto (Cuadro 1). Este consenso social necesita un relato en formas diversas, algunas de las cuales dejan rastros arqueológicos susceptibles de estudio. Diversos autores se han interesado por este tipo de estudios, aunque con importantes diferencias en su fundamento y aplicación al registro arqueológico. Veamos, de forma crítica y resumida, las principales aportaciones y el estado actual del que partimos.

\subsection{Teorías y métodos de la Arqueología cognitiva}

En el desarrollo de la Arqueología se han producido diversos enfoques teóricos sobre la interpretación de los datos arqueológicos, dando lugar al inicio y desarrollo de la Arqueología cognitiva con diversos enfoques metodológicos. 


\subsubsection{Procesualismo o Nueva Arqueología}

En su inicio se planteó la posibilidad de conocer el funcionamiento de las mentes de los seres humanos de otras épocas a partir de los datos arqueológicos, pues se consideró que el pensamiento y la acción son procesos indisociables, por lo que los objetos serían el resultado del pensamiento (Renfrew y Bahn 2007). Con este fundamento se elaboraron teorías generales sobre el origen y desarrollo del pensamiento humano, asumiendo que los símbolos de cualquier grupo humano tienen siempre el mismo orden de racionalidad. Se dio prioridad a la existencia de una Razón Universal en los procesos cognitivos y al positivismo de sus conclusiones, objetivando el fenómeno de la cognición. Entre los autores que se han dedicado a este tema podemos destacar los siguientes:

- Andrew Colin Renfrew (1982, 1993) es el primero en conceptuar a los estudios simbólicos y cognitivos como una Arqueología cognitiva. Intenta reconocer las características de la conducta inteligente a través de los restos materiales, por medio de estudios interdisciplinarios, al correlacionar datos de la Psicología, Etología, Inteligencia artificial, la Neurociencia y la Arqueología. Para él, la Arqueología cognitiva tiene como objetivo la búsqueda del significado que los símbolos y representaciones tuvieron para aquellos que los utilizaron. Establece el concepto de la "sapient paradox", en referencia al desfase entre la creación evolutiva de nuestra especie y la muy posterior aparición de la conducta simbólica. Comprende que las capacidades cognitivas se establecieron evolutivamente hace más de 60.000 años (quizás 200.000 años), pero las conductas propias de nuestro cerebro no se establecieron hasta mucho después (hace 10.000 años), por lo que su aparición tiene los aspectos de emergencia conductual. La base neurológica de la evolución cognitiva humana no puede estar basada en una especificación neurológica o de modulación mental innata, sino en una modulación neurológica (plasticidad neuronal y enseñanza) motivada por las características medioambientales. Nuestro cerebro se adapta a las condiciones en las que vive, sobre la base de la socialización de la experiencia compartida, facilitando el desarrollo de factores cognitivos emergentes de la mente humana. Así, el lenguaje simbólico es imprescindible para que la humanidad pueda alcanzar su característico desarrollo cultural (Renfrew 2008).

- Merlin Donald (1991) realiza un trabajo interdisciplinario al coordinar teorias de Antropología, Arqueología, Psicología cognitiva, Lingüística y Neurología, donde la cultura material desempeña un papel activo en la formulación y comunicación de los procesos cognitivos. Construye un esquema de tres sucesivas revoluciones sobre el modo en que la mente maneja la información almacenada (evolución de los modos de representación), apareciendo en cada uno de ellos cambios cognitivos y un nuevo estadio de conciencia (conciencia episódica, mimética, mítica y teórica). Lo explica por medio de un proceso evolutivo asimilable a los equilibrios puntuados, en las áreas corticales de asociación, del hipotálamo y del cerebelo. En el Homo sapiens se produjo una evolución cognitiva y cultural, sustentada por las formas de memoria externa y una nueva arquitectura de la memoria de trabajo. La mente moderna se caracteriza por la constante integración y reelaboración de experiencias a través de múltiples formas de representar la información. La última forma es la memoria externa que se suma y potencia a la memoria de trabajo de carácter biológico. Adquirimos el conocimiento simbólico desde fuera hacia dentro, por lo que el lenguaje y los símbolos son esencialmente sociales.

- Willian Noble y lain Davidson (1996) también realizan un trabajo interdisciplinario sobre el origen de la cognición y lenguaje humano. Utilizan la Psicología, Lingüística, Antropología y Arqueología, así como un uso más limitado de la Biología evolutiva y Neurología. Explican el origen de la mente dentro del desarrollo ontogénico, principalmente de forma sincrónica con el lenguaje, el cual está unido al concepto de mente, considerando a ambos como co-extensivos. Las palabras son abstracciones mentales simbolizadas por los sonidos, totalmente ligadas a la existencia social humana. Hay acuerdo en que la conciencia fue probablemente transformándose por la adquisición del lenguaje, aunque se desconoce cómo ocurrió esta transformación. En los niños se produce una mentalidad emergente, con apropiación de las intenciones lingüísticas de la familia y otros contextos sociales, por lo que lo mental estaría inevitablemente implicado en la producción del lenguaje. La autoconciencia libera a la gente de las contingencias inmediatas del natural medioambiente. La abstracción es un proceso vital en la formación de conceptos, pues todas las palabras son abstracciones simbolizadas, siendo usadas (escuchadas, aprendidas y utilizadas) constantemente. El pensamiento es como un proceso perpetuamente dialogado, en el cual el diálogo es con uno mismo (lenguaje interno), por lo que se puede considerar al pensamiento como una conducta lingüística socialmente construida. En definitiva, el lenguaje es una actividad comunicativa (social) y medio para la construcción del pensamiento (conducta cognitiva). 
- Lambros Malafouris (2008) centra su pensamiento en el surgimiento de la autoconciencia. La cuestión del yo no puede extrapolarse fácilmente del registro arqueológico, siendo esencialmente un problema de nuestra relación con el mundo material. El yo excede de los límites del cerebro, situándose entre éste, los cuerpos y las cosas, siendo el resultado de la persistente interacción de estos tres elementos. Esto nos lleva a una conciencia especial que Ilama tectonoetic, que es como una construcción continua e interactiva entre el sistema nervioso y el medio extraneural (cuerpo y cosas). En este proceso la memoria es clave para la constitución de un si mismo como un objeto histórico (memoria episódica), y su formación a partir de los datos externos conformando lo que llama memoria expandida (Malafouris 2010). La estructura funcional del cerebro es una construcción dinámica que se remodela constantemente por medio de las experiencias importantes, muchas veces creadas por objetos materiales (bastón de ciego, anillos, etc.), que se relacionan con acontecimientos pasados, presentes y futuros, dependiendo de su uso y propiedad. El yo es el resultado de la interacción permanente de la mente, el cuerpo y el medio.

- Steven Mithen (1998) intenta comprender las características y condiciones que originaron la evolución de la mente humana, y cómo se ha ido estructurando. Para ello realiza un trabajo interdisciplinar con los datos de la Psicología evolutiva, Neurología, Primatología, Biología evolutiva, Arqueología, Etología y Lingüística. Elige la Psicología evolutiva, la cual está muy comprometida con un darwinismo tradicional, donde la evolución conforma gradual y selectivamente nuestro pensamiento, creando diferentes módulos cognitivos de acción independiente. El medio social y el lenguaje permiten la evolución cultural y el desarrollo cognitivo, pues el lenguaje es el medio de unión entre las distintas inteligencias: social (manejo de las relaciones interpersonales), técnica (manipulación de objetos), histórico-natural (comprensión de las relaciones causa-efecto), logrando una fluidez cognitiva entre todos ellos, y la conducta moderna del Homo sapiens. La fluidez comenzó cuando el grupo social empezó a hacerse más numeroso y complejo, alcanzando su máxima potencialidad hacia 60.000 BP.

- Thomas Wynn $(1981,1985)$ en un principio relacionó la evolución de la mente de nuestros antepasados con los restos arqueológicos por medio de una teoría del psicólogo J. Piaget (1952) sobre el desarrollo cognitivo de los niños. En ésta, se indica una secuencia de varios estadios evolutivos durante su crecimiento (sensoriomotor; preoperacional; de operaciones concretas y de operaciones proposicionales). La inteligencia humana, en la evolución de su género, fue adquiriendo evolutivamente cada uno de estos estadios, lo que le permitió ir desarrollando su tecnología y comportamiento.

Su evolución teórica le hace ver la necesidad de elaborar formas explicativas más concretas, lo que realiza junto al psicólogo Frederick L. Coolidge (2004, Coolidge y Wynn 2011). La neurociencia identifica claramente una capacidad de planificación y resolución de problemas que es neurológicamente aislable del comportamiento simbólico y de las habilidades del lenguaje. Este componente del pensamiento moderno es la memoria de trabajo. Su teoría principal sobre la evolución de la moderna cognición se basa en que un reciente aumento de la capacidad de la memoria de trabajo fue la última pieza evolutiva que posibilitó el desarrollo de las capacidades cognitivas propias de nuestra especie. El fundamento psicológico es la clave de su teoría, pues expresa una independencia cognitiva de la memoria de trabajo. La evidencia arqueológica indica que la memoria de trabajo tuvo una mejora hacia las características modernas en un pasado relativamente reciente, hace 30.000 años, pero su evidencia es dispersa y puede alargarse hasta los 77.000 años atrás. La mejora de esta capacidad fue uno de los desarrollos evolutivos finales que produjeron la mente moderna, dentro del concepto de evolución en mosaico de la cognición humana.

La mayoría de los procesualistas han desarrollado amplias teorías generales sobre la conducta humana (Colin Renfrew, Merlin Donald, Davidson y Noble, Mithen, Wynn y Coolidge, etc.), la mayoría con criterios interdisciplinarios, pero no lo suficiente como para evitar los problemas que se les achacan. Se les critica la falta de objetividad de sus estudios, pues reflejan conceptos y formas de pensar actuales, como las del propio investigador (Hernando 1999), lo que únicamente puede corregirse, hasta cierto punto, con un método interdisciplinar amplio y adecuado. Igualmente, tienen problemas para aplicar sus conceptos generales a las particularidades contextuales de cada yacimiento. Su principal causa es la falta de un método básico sobre la forma en que las características psicobiológicas humanas adquieren y procesan la información del medio ambiente y la transmiten generacionalmente, lo que en definitiva es el germen de todo origen y desarrollo conductual (Rivera 2009, 2010).

\subsubsection{La arqueología postprocesual o interpretativa}

En su origen intentaba superar las limitaciones positivistas y materialistas de la Nueva Arqueología y evitar la subjetividad de la mente del investigador. Los fracasos en la creación de leyes generales para el comportamiento humano hacen que la interpretación del mismo recaiga en el análisis 
detallado y particular de cada determinado contexto, aunque en su estudio siempre aparecen las ideas actuales y las propias preconcepciones del arqueólogo.

El principal valedor de estas ideas ha sido lan Hodder que propone un modelo sobre el comportamiento individual y social con una referencia explícita a la cognición humana (Arqueología cognitiva post-procesual o Interpretativa), donde el contexto arqueológico adquiere una particular importancia. Ante la imposibilidad de escapar a la subjetividad (consciente o inconsciente) del investigador, y puesto que su estudio sólo puede realizarse por medio de nuestro conocimiento académico y forma de pensar actual, hay que intentar comprender cual fue el modo con el que fueron percibiendo la realidad en el pasado, con toda seguridad diferente a las formas que utilizamos en la actualidad. Con estos condicionantes intentan comprender lo ocurrido en el pasado por medio de un análisis teórico, que aclare la intención que pudieron tener los creadores de los restos arqueológicos, mediante la intuición del investigador dentro de un preciso contexto arqueológico. Defendió explícitamente el fundamento hermenéutico de la Arqueología Interpretativa, en el que todo estudio de lo cognitivo es un estudio del significado de un acto o un bien dentro de un contexto social. Su forma de actuar, en la interpretación de objetos, se basa en la asignación de significados a los mismos, que suponen deben ser los mismos que daban sus autores en el pasado. La Arqueología sería un procedimiento relativo cuyo método no sólo consiste en analizar los restos procedentes de una excavación, sino también las actitudes y opiniones que suscita. Surgirian diversas interpretaciones del yacimiento en particular (de género, estructurales, sociales, económicas, cognitivas, etc.), con la meta de poder llegar, por medio de la diversidad explicativa de cada yacimiento, a conocer mejor el pasado humano (Hodder 1991, 1993).

A los postprocesuales les es muy difícil realizar trabajos generales a partir de sus estudios contextuales, pues les falta una metodología que pueda compaginar ambos campos de aplicación. Igualmente, cualquier tipo de análisis realizado sin un mínimo conocimiento de la funcionalidad psicobiológica humana, que controle y limite las posibilidades de explicación, hace que se caiga en una subjetividad parecida a la que se atribuyó a los procesualistas.

\subsubsection{Estructuralismo}

El Estructuralismo intenta, a través de una interpretación lo más objetiva y metodológica posible, crear formas interpretativas de la conducta humana que puedan superar las limitaciones teóricas y prácticas del procesualismo y postprocesualismo.

A mediados del siglo XX, el Estructuralismo pareció que podría ser el marco teórico adecuado para relacionar la conducta arqueológica con los conceptos de la Psicología y la Neurología. Éste se centró en la existencia de estructuras o modelos genéricos de conducta (reglas conductuales), invi- sibles, inconscientes y universales, que condicionan el comportamiento humano (Lévi-Strauss 1964). Las estructuras de percepción (sentidos) y procesamiento de la realidad (cerebro) otorgan una forma básica y común de conocer e interpretar la realidad a todos los seres humanos (códigos comunes). Sin embargo, la Psicología y la Neurología tenían un desarrollo reducido en esta área de conocimiento cuando se elaboró el paradigma estructuralista, lo que limitó sensiblemente su base teórica y su fundamentación científica, propiciando modelos de análisis con escaso fundamento psicobiológico. En la aplicación arqueológica su nivel de subjetividad fue superior al que se pretendía corregir, recibiendo numerosas críticas y dando la sensación de un camino poco útil.

En la actualidad es posible desarrollar un modelo teórico basado en lo común de todos los seres humanos, pero independiente de los aspectos particulares de sus numerosas culturas. Su utilidad se limitaría al uso de aquellos factores comunes o estructurales de nuestro género biológico. Con la información actual de la Biología evolutiva, Neurología, Psicología cognitiva (procesamiento de la información), Paleogenética, Lingüística (Neurolingüística) y Antropología cultural se ha podido elaborar un estructuralismo funcional, es decir, una base psicobiológica sobre la que se va a desarrollar nuestro pensamiento y conducta (Damasio 2010). No obstante, la forma en que esta percepción y procesamiento de la realidad va a dar lugar a la construcción cultural (económica, tecnológica, social y simbólica) sería diferente entre los humanos del pasado y del presente, pues cada uno estaría condicionado por las características medioambientales espaciales y temporales del momento en el que le tocó vivir (Hernando 1999). Lo que en un principio es común, en su desarrollo se diversificaría, lo que explica el aspecto de mosaico (cultural y cognitivo) que caracteriza tales procesos, algunos tan debatidos como la transición al Paleolítico superior (Straus 2005) o el carácter heterogéneo temporal y espacial de la evolución cultural (D'Errico y Stringer 2011).

Sus fundamentos interdisciplinarios permiten crear una metodológica que facilite la elaboración de trabajos genéricos a partir de los particulares datos del registro arqueológico, que en definitiva deben ser la guía del desarrollo conductual humano. Se pueden establecer leyes generales sobre la forma de crear y desarrollar la conducta humana, pero con la suficiente flexibilidad como para que se adapten a las particularidades, sociales y personales de cada contexto arqueológico, y explicar la diversidad cultural y cognitiva como características esenciales de la conducta humana.

\subsection{Concepto interdisciplinar del estructuralismo funcional}

Este concepto se fundamenta en la acción coordinada de las características psicobiológicas, evolutivas y lingüísticas que existen en las diferentes especies del género hu- 
mano, ampliamente descritas por uno de nosotros (Rivera 2003-2004, 2005, 2009). De esta coordinación podemos resaltar las siguientes conclusiones básicas:

- La evolución biológica nos va dotando de unas capacidades funcionales innatas (capacidades cognitivas elementales o básicas) de origen evolutivo como son la memoria, funciones ejecutivas (memoria de trabajo, planificación, flexibilidad, monitorización e inhibición) atención, motivación, creatividad, razonamiento, percepción, etc. Su repercusión en la conducta no sólo depende de su potencialidad efectiva, sino del desarrollo de las mismas (desarrollo cognitivo) (Vygotsky 1979; Baquero 2004). Es decir, tenemos las capacidades (el hardware) pero hay que desarrollarlas (crear y aplicar el software adecuado).

- Las características neurológicas y psicológicas (psicobiológicas) del sistema nervioso humano muestran la necesidad de un medio ambiente adecuado que hay que crear (social, económico, tecnológico, lingüístico, etc.) para que las capacidades cognitivas básicas se desarrollen adecuadamente. Podría definirse como un nicho cultural o cognitivo que posibilite su desarrollo (Tomasello 2007; Bickerton 2009).

- Cuando la evolución neurológica sea adecuada y las características ambientales adquieran el nivel suficiente puede producirse la manifestación de nuevas capacidades de naturaleza sociocultural, las cuales sólo existían como potencialidad. Son las capacidades cognitivas emergentes o superiores (p. e. la conducta simbólica, la autoconciencia, lenguaje simbólico, escritura, etc.) (Baquero 2004; Vygotsky 1979). Para un desarrollo cognitivo emergente de naturaleza simbólica es necesario alcanzar unos determinados niveles de desarrollo demográfico, socioeconómico y tecnológico (Tomasello 2007; Ardila y Ostrosky-Solís 2008; Malafouris 2008; Renfrew 2008) (Cuadro 2).

- Cualquier acción individual o social incluye un componente emocional (Ardila y Ostrosky-Solis 2008). Por tanto las capacidades cognitivas siempre tienen un carácter racional y emocional.

- La existencia de un lenguaje (primera conducta simbólica) es condición necesaria, aunque no suficiente, para la formación, desarrollo y transmisión de todas las conductas simbólicas. Entendemos por lenguaje humano cualquier intento de transmisión social de aquellos procesos que hayamos podido simbolizar por cualquier medio (sonoro, gesticular, visual, etc.), con la intención de realizar acciones comunes. Así, el pensamiento, la conducta y

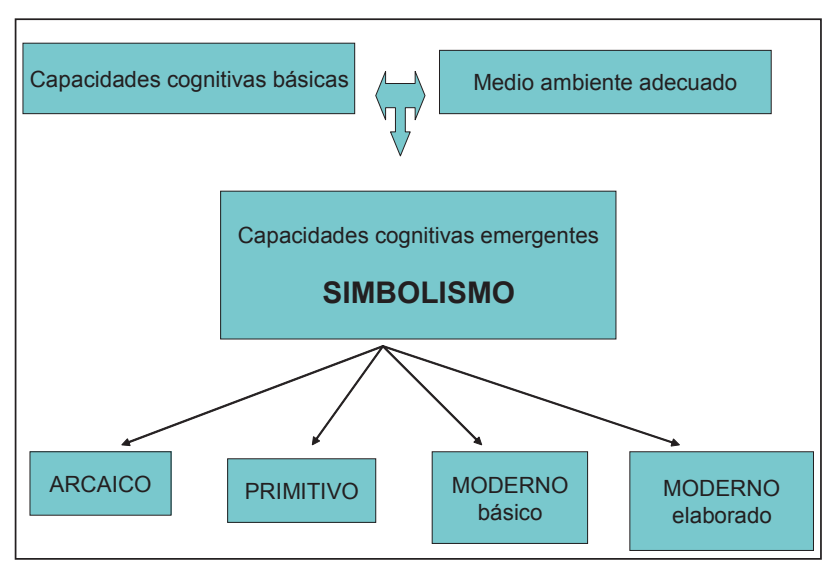

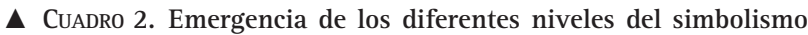
humano según el desarrollo acumulativo de las capacidades cognitivas básicas en el nicho cultural adecuado.

el lenguaje son tres vertientes del mismo proceso psicobiológico que va a caracterizar a los seres humanos. De la información del registro arqueológico (conducta) podemos realizar inferencias sobre las características del pensamiento y lenguaje. Las conductas básicas, con las que podemos comprobar arqueológicamente los niveles de evolución del pensamiento y lenguaje, son la individualidad social y personal, así como su relación con los conceptos temporales y espaciales (Cuadro 3).

\subsection{Características generales del simbolismo humano}

El simbolismo moderno humano es el resultado de un proceso cognitivo emergente, consecuencia del desarrollo de ciertas capacidades cognitivas básicas en un medio ambiente adecuado, como hemos visto. De estas capacidades elementales, por sí solas, no se puede intuir ni explicar tal emergencia (Edelman 1994; Edelman y Tononi 2000; Searle 2000; Mora 2001; Rivera 2005, 2009; Álvarez Munárriz 2005; Tomasello 2007; Ardila y Ostrosky-Solís 2008, etc.). Este proceso es acumulativo, pues en su desarrollo utiliza anteriores conceptos (simbólicos o no) más elementales, pero imprescindibles para la evolución hacia la simbolización. Para su logro se necesita cierta estabilidad demográfica que facilite su perduración, transmisión generacional y progreso. En resumen, la emergencia de la conducta simbólica (empezando por el lenguaje) es un proceso basado en los mecanismos de exaptación de la evolución biológica (Bickerton 2009).

La evolución cultural y simbólica constituyen un continuum que adquiere un aspecto de heterogeneidad temporal y espacial, pues depende de diversos factores (capacidades y desarrollo cognitivo, existencia de un lenguaje previo, medioambiente sociocultural, condiciones demográficas, etc.) que no siempre actúan con la misma intensidad ni han adquirido el adecuado desarrollo en todas las áreas geográ- 
ficas, lo que implica una escala regional de análisis para la observación de los rasgos que fosilizan. En este continuum se producen diversos estadios intermedios, de los que desconocemos sus características precisas, pero que podemos proponer hipotéticamente y contrastar con los datos conocidos del registro arqueológico. Debe tenerse en cuenta que los conceptos y abstracciones que van a configurar el simbolismo humano en todos sus niveles han de adquirirse de la observación del medio ambiente en el que se vive, tanto de la propia naturaleza como de las construcciones sociales que los grupos humanos vayan creando. Debe destacarse el desarrollo lingüístico, primera e imprescindible manifestación simbólica humana. La conducta lingüística permite y condiciona la creación, mantenimiento y transmisión de todo simbolismo.

\subsection{Los niveles del simbolismo humano}

Las propiedades acumulativas y emergentes del simbolismo humano lo definen como una construcción progresiva que permite su estructuración histórico-evolutiva en diferentes niveles (Rivera 2003-2004, 2009, 2010). Planteamos la hipótesis de cuatro grandes estadios evolutivos que puedan relacionarse con los datos del registro arqueológico y de la evolución lingüística, como intentaremos mostrar más adelante (Cuadro 4). No obstante, siempre hay que tener en cuenta que su desarrollo casi nunca es lineal, pues en cada región y tiempo su evolución tiene sus propios ritmos, dependiente de las características cognitivas de sus creadores y del medioambiente sociocultural que hayan podido elaborar.

I. Simbolismo arcaico o básico. Se formó con la simbolización de las ideas elementales relacionadas con la convivencia social y la supervivencia del grupo, por medio de sonidos y/o gestos que socialmente serían conocidos. Se inicia con un desplazamiento cognitivo de la acción (evolución de las acciones fuera del aquí y ahora), aunque de forma muy limitada. Tal avance cognitivo facilitaría las acciones conjuntas (convivencia, tecnología, logística, etc.), y desarrollaría el concepto social del grupo. Sus usuarios no tendrían conciencia de utilizar tal proceso simbólico. Pudo incluir en Europa a una parte de los H.heidelbergensis de cultura Achelense y a tipos humanos anteriores.

II. Simbolismo primitivo. Al anterior se fueron sumando los avances en los conceptos de individualidad social y personal, así como de una mayor ubicación temporal y espacial. Sería fundamentalmente descriptivo, lingüístico, sin descartar una base gesticular, con elementos sintácticos elementales e inconscientes. Se mostraría en la aparición de

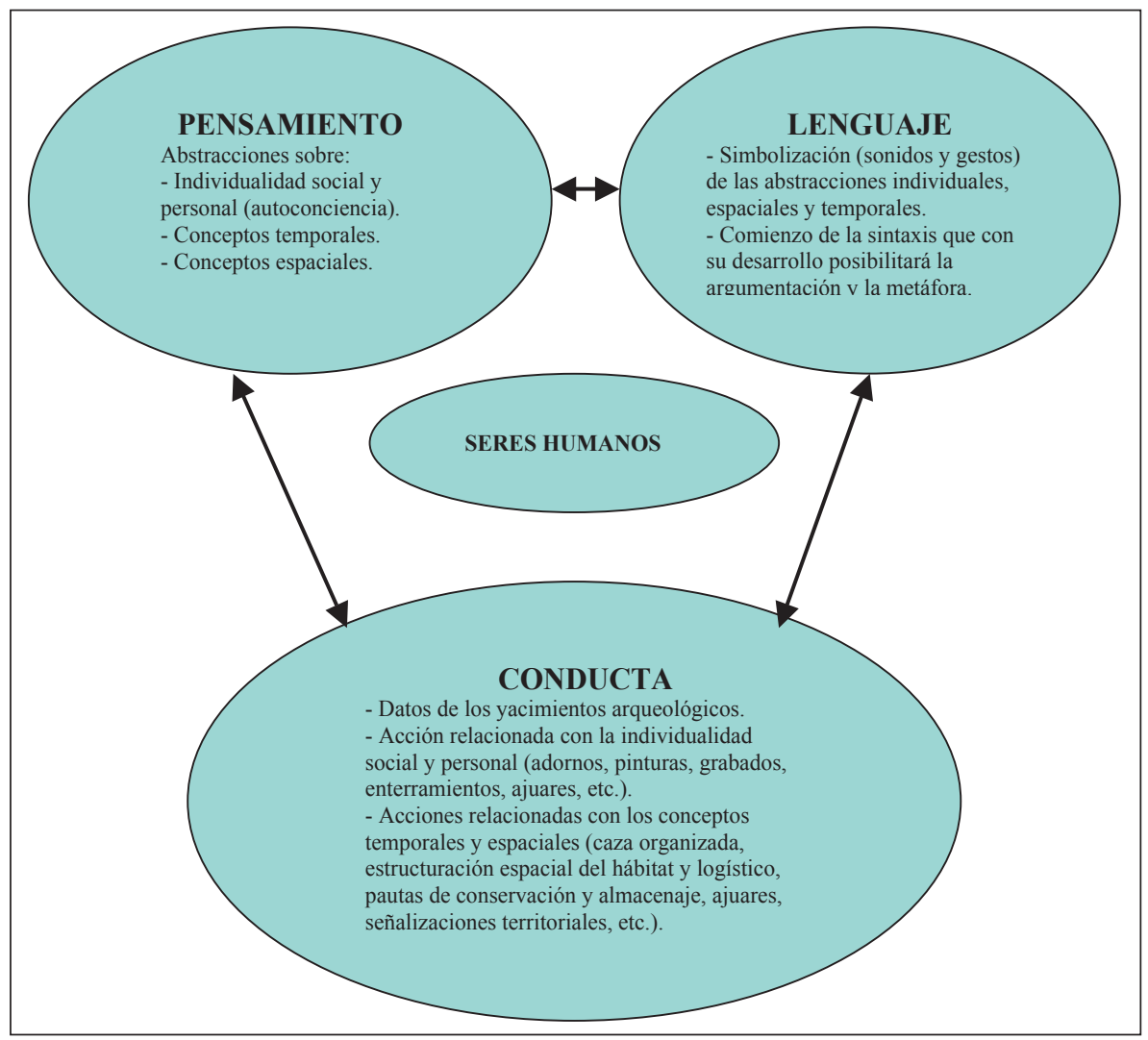

A CuAdro 3. Relación existente entre el pensamiento, lenguaje y conducta, de tal manera que conociendo uno de ellos (conducta) pueden realizarse inferencias en los otros dos componentes de la cognición humana. Los parámetros sobre los que se desarrollan estos procesos cognitivos son la individualidad social y personal, así como los conceptos temporales y espaciales. 
Cuadro 4. Diferentes etapas evolutivas de la emergencia en la simbolización y sus marcadores arqueológicos (NO/SÍ indica una presencia restringida a ciertas áreas o yacimientos solamente).

\begin{tabular}{|c|c|c|c|c|c|c|}
\hline SÍMBOLISMO & Arcaico & Primitivo & Moderno básico & \multicolumn{3}{|c|}{ Moderno elaborado } \\
\hline Lenguaje & Fonológico & Síntáctico & Argumentativo & \multicolumn{3}{|c|}{ Metafórico } \\
\hline Religión & NO & NO & NO & $\begin{array}{c}\text { Conductas } \\
\text { espirituales } \\
\text { protoreligiosas }\end{array}$ & $\begin{array}{l}\text { Conductas } \\
\text { religiosas } \\
\text { sin estructurar }\end{array}$ & Religión \\
\hline Enterramientos & NO & sí & sí & sí & sí & sí \\
\hline Adornos & NO & NO & sí & sí & sí & sí \\
\hline Esculturas & NO & NO & NO & NO/Sí & sí & sí \\
\hline $\begin{array}{c}\text { Arte rupestre anicónico } \\
\text { exterior }\end{array}$ & NO & NO & NO & NO/Sí & sí & sí \\
\hline $\begin{array}{c}\text { Arte rupestre icónico } \\
\text { exterior }\end{array}$ & NO & NO & NO & NO & sí & sí \\
\hline $\begin{array}{c}\text { Arte rupestre } \\
\text { anicónico interior }\end{array}$ & NO & NO & NO & NO/Sí & sí & sí \\
\hline $\begin{array}{l}\text { Arte rupestre icónico } \\
\text { interior }\end{array}$ & NO & NO & NO & NO & NO/Sí & sí \\
\hline Cultura arqueológica & Achelense & $\begin{array}{l}\text { Achelense } \\
\text { Musteriense }\end{array}$ & $\begin{array}{l}\text { Musteriense } \\
\text { Auriñaciense }\end{array}$ & Auriñaciense & $\begin{array}{l}\text { Auriñaciense } \\
\text { Gravetiense }\end{array}$ & Gravetiense \\
\hline
\end{tabular}

conductas complejas relacionadas con el desarrollo de estos conceptos (áreas diferenciadas en el hábitat, enterramientos intencionados, tipología y tecnología lítica con referentes culturales, logística previsora, etc). Incluye a tipos heidelbergensis, a una parte de los HN de cultura musteriense y a los primeros HAM en África y el Próximo Oriente.

III. Simbolismo moderno básico. Se alcanza con un importante desarrollo del estadio anterior, es decir, del incremento de la individualidad social y personal, junto con una ubicación temporal y espacial perfeccionada, lo que impulsaría un pensamiento y lenguaje de nivel argumentativo. Sería el inicio de un simbolismo consciente y social, al ser usado con la intención expresa de funcionalidad y argumentación (marcar las diferencias sociales o individuales y gestionar conductas complejas). Se produce con el HAM de cultura auriñaciense y con algunas poblaciones de HN musterienses o de las Ilamadas culturas transicionales. Su simbolismo pudo limitarse a las manifestaciones socioeconómicas y personales de la vida cotidiana.

IV. Simbolismo moderno elaborado. Tras el desarrollo anterior, y como premisa necesaria, se comienza a crear una conducta más compleja y con gran capacidad de simbolización. Se caracteriza por el desarrollo de un simbolismo social, espiritual y religioso progresivamente complejo, que emerge en etapas sucesivas. Este simbolismo tendría un lenguaje no sólo argumentativo, sino también metafórico, siendo consciente, intencionado y utilizado para explicar muchos aspectos conductuales de la vida individual y social, así como dar una explicación de lo metafísico o sobrenatural. Este nivel se desarrolla de forma progresiva y heterogénea exclusivamente con HAM durante el Auriñaciense, en algunas áreas, y se generaliza con el Gravetiense al continente europeo.

\section{ORIGEN, DESARROLLO Y CARACTERÍSTICAS DE LAS CONDUCTAS SIMBÓLICAS}

Existen determinadas características biológicas y culturales que nos definen, vistas desde el presente, como humanos frente a los restantes animales. La evolución de nuestro género biológico muestra que han existido diferentes maneras de ser humano. Que ese proceso ha sido un continuum emergente y acumulativo, con diferentes estadios incluso en una misma especie. Por tanto, a ser humano se "aprende" (incesto, antropofagia, sentimientos de compasión y amor, religión, etc.). Por ello, los diferentes componentes de lo que va definiendo una conducta como humana no han existido siempre, sino que tuvieron que surgir de las capacidades cognitivas de los homínidos de cada periodo y de su desarrollo en función del medio ambiente. Desde el inicio de la conducta simbólica habría que diferenciar dos planos de desarrollo cognitivo y conductual: uno eminentemente social (individual y colectivo), de carácter doméstico; y otro, posterior, sobre aspectos no materiales o cotidianos con un componente espiritual y/o religioso. El segundo depende del desarrollo del primero, por lo que tienen orígenes diferentes, aunque actúen de forma interrelacionada.

\subsection{Los componentes básicos del simbolismo moderno. El lenguaje humano}

Las primeras manifestaciones del simbolismo debieron ser de tipo lingüístico, aunque realizadas de forma inconsciente. Sólo se simbolizarian las abstracciones sobre las necesidades vitales o sociales, pero expresadas para que los demás componentes de la sociedad lo entendiesen, y poder 
realizar conductas comunes (Rivera 2009). El lenguaje es una representación o simbolización de la experiencia (pasada, presente y futura) de esa sociedad, ya sea directamente 0 por procesos de combinación basados en anteriores vivencias (memoria, escritura, dibujos, etc.). En este sentido, la acción es la base de la propia estructura inicial de lenguaje y de la universalidad de su sintaxis, pues es igual en todas las geografías y en todos los periodos históricos (Fillmore 1968; Bruner 1984; Bickerton 1994; Marina 1998).

Para iniciar una conducta (o para simbolizarla con un lenguaje) siempre hay que expresar alguna referencia sobre la acción: quién la hace, y dóndey cuándo se produce, características que van a constituir los componentes básicos del simbolismo. Los humanos del paleolítico estaban plenamente integrados en el mundo natural en el que vivían, pero en la naturaleza no son evidentes tales conceptos abstractos. Deben formularse mediante procesos cognitivos -abstracción-, y simbolizarlos mediante sonidos o gestos -lenguajetras un consenso social sobre estos tres componentes básicos.

El concepto de humanidad está fundamentado en la convicción de la existencia de una vida mental semejante a la nuestra en los otros componentes de la sociedad (teoría de la mente). Al intervenir varios sujetos su origen y evolución estarían condicionados a las características de las relaciones sociales (Edelman 1994; Tomasello 2007). La adquisición del concepto de diferenciación personal (quién) respecto de los demás como componente fundamental de la autoconciencia, así como del grupo social respecto a otros, surgiría de la apreciación de las diferencias que puedan existir entre los miembros de un mismo grupo, o entre poblaciones diferentes. (Elías 1990; Jenkins 1996; Hernando 1999; Rivera 2005, 2009). Sería el desarrollo de la conciencia autobiográfica que incorpora las dimensiones sociales y espirituales del pasado y posibilita el futuro anticipado (Damasio 2010). Las diferencias biológicas dependerian de los procesos evolutivos, pero las culturales y demográficas hay que crearlas, pues no han existido siempre. Con este progreso aparecen las necesidades sociales de recalcar tales diferencias, es decir, de crear referencias visibles que muestren la individualidad personal y su estatus frente al grupo (los adornos, por ejemplo), y del grupo local o regional frente a otros (industrias líticas $u$ óseas, signos rupestres, etc.). Hasta que estas condiciones no existieran, es difícil creer en el inicio de un simbolismo de características modernas. Así, la individualidad social y personal no es una cualidad cognitiva de manifestación espontánea, sino que necesita del medio ambiente adecuado para desarrollarse, formando parte de él, pues es este ámbito (social, cultural, simbólico, etc.) el que va a configurar definitivamente el inmaduro cerebro de los niños con las características propias de cada lugar (Malafouris 2008; Renfrew 2008; Damasio 2010), posibilitando y perpetuando el proceso.

El espacio (dónde) se objetiva con la referencia a entidades fácilmente observables, inmóviles y permanentes, como características persistentes (geológicas o geográficas) del territorio donde se realiza la propia vida (montañas, ríos, árboles, etc.), y donde se adquieren los elementos básicos de su subsistencia (caza, recolección, materias primas, relaciones sociales, etc.). El concepto del tiempo (cuándo) se obtiene con la referencia de sucesos móviles de carácter no humano, pero con un tipo de movimiento recurrente. La abstracción temporal nace del orden de sucesión de los hechos que tienen lugar en el espacio ya mencionado (dia y noche, estaciones, fases de la luna, etc.) (Hernando 1999). El desarrollo y manejo de estas abstracciones en el lenguaje cotidiano son condiciones imprescindibles para que aparezca el contexto donde se desarrolle el simbolismo moderno; su logro en niveles adecuados permite la emergencia de una conducta reflexiva y flexible, y por ello previsora, adaptativa e innovadora, es decir, mucho más eficiente.

Por tanto, la conducta simbólica, considerada inicialmente como moderna básica, aparece cuando se adquieren las abstracciones de individualidad, espacio y tiempo con un desarrollo adecuado. Para lograr este desarrollo cognitivo es necesaria la propia interacción social entre los miembros del grupo y con otros grupos (Shennan 2001; Powell 2009), la consecución de un determinado nivel de desarrollo socioeconómico de estas poblaciones y la existencia de un lenguaje con elementos de identificación social y/o personal, junto con su ubicación temporal y espacial. Así, el nacimiento y desarrollo de este simbolismo moderno deberá ir asociado a situaciones arqueológicas en las que se observe un aumento demográfico en una determinada área geográfica, y con cierta evolución socioeconómica (Hernando 1999). Todo proceso simbólico es fundamentalmente social, manifestándose en el registro arqueológico por medio de los marcadores de individualidad, como los adornos personales (colgantes, pinturas corporales) y los comportamientos funerarios, así como los marcadores grupales en los modos culturales identificables (industrias líticas $u$ óseas, arte mueble) o en las señales gráficas añadidas intencionalmente (pinturas y grabados) y no exclusivamente utilitarias.

\subsection{Simbolismo espiritual y religioso}

El inicio del simbolismo espiritual y religioso responde más a la reflexión que a la experiencia pues, por sus características inmateriales, no se adquiere por la observación de la naturaleza o de la sociedad. Es preciso buscar procesos cognitivos humanos que de alguna manera favorecieran la concepción de un mundo diferente al cotidiano, y que aunque sea de naturaleza inmaterial se perciba como real. En nuestro medio psicobiológico y social sólo los estados de conciencia diferentes o alterados respecto a la conciencia normal pueden servir como fuente de inspiración de estos conceptos, mientras que en el mundo paleolítico serían considerados como normales y reales, y como tales se utilizarian. Para su realización es imprescindible que se tengan suficientemente desarrollados 
los conceptos del yo-otros, de un espacio amplio y diverso, dentro de un tiempo pasado, presente y futuro, pues son características básicas de toda experiencia cognitiva de carácter simbólico, ya sea material o inmaterial (Alvargonzález 2005; Bueno 1996). Con la emergencia de un adecuado nivel de autoconciencia durante la fase de simbolismo moderno básico, los sueños o alucinaciones pasan a ser conscientes, propios y reales. Éstos siempre habian existido, naturalmente, pero no podían aflorar al plano consciente sin el desarrollo de la autoconciencia. Este proceso se puede definir como una emergencia de contenido onírico o alucinógeno que habria que interpretar, comunicar y explicar, lo que se puede intentar con manifestaciones gráficas o conductuales. Estos estados pueden ser incontrolables, como los sueños o las alucinaciones por enfermedad (fiebre, alteraciones psiquiátricas, comas superficiales, etc.); o bien más o menos controlables, como los inducidos por drogas o rituales frenéticos.

En la vieja idea animista de Tylor estos estados alterados de conciencia (sueño) muestran la posibilidad de que el alma se pueda separar de su morada material y así se le confiere entidad propia e independiente, apareciendo el concepto de seres espirituales, que se podrán aplicar a otras criaturas y objetos que acabarán condicionando las vidas de los seres materiales al convertirse en dioses. Así nace la religión para Tylor (1871). Pero pasar de la idea de alma a la de espíritu no parece justificado, son conceptos diferentes. Los estados alterados de conciencia que hemos aludido y las experiencias que en ellos tienen los individuos (Lewis-Williams 2005) suponen la intuición de que tras estas extrañas percepciones se manifiesta la posibilidad de otro plano de existencia, de "otro mundo", diferente del cotidiano. Un mundo complejo, inmaterial y con entidades que muestran propiedades diferentes de las conocidas entre los seres humanos. Su aceptación implica el desarrollo de un simbolismo espiritual (de base no material en el sentido más estricto), basado no sólo en tener ensoñaciones o alucinaciones, sino en adquirir la conciencia de que uno mismo las tiene como entidades externas a él, y admitir la posibilidad de la existencia de una realidad inmaterial. El carácter acumulativo de las percepciones cognitivas, que hemos visto, implica la existencia previa de capacidades cognitivas suficientes para ello (simbolismo moderno básico).

¿Cómo definir los componentes y cualidades de ese mundo inmaterial? Tomamos de la Filosofía de la Religión el término latino numen que es una categoría "eminentemente religiosa, pero no es por necesidad divino" (Bueno 1996). Las relaciones de los humanos con los númenes o lo numinoso, aunque cambiante en cada época, siempre se desarrolla en el ambiente de la espiritualidad y/o religiosidad, que en un principio serian simplemente narraciones o mitos. En nuestro ámbito de análisis hablaremos de númenes paleolíticos, con sus características en gran parte desconocidas.

Sin embargo aparece un nuevo problema: ¿Qué tipo de relación puede establecerse entre los humanos y estos númenes? De la propia toma de conciencia de las características de las ensoñaciones o alucinaciones de los estados alterados de conciencia es fácil apreciar que tenían cualidades diferentes de los seres humanos y animales reales. En ellos los animales o las personas presentan unas características de movilidad especiales (inalcanzables, dificultad de movimientos, etc.), situación espacial y de relación social e individual (flotando en un medio aislado) que no obedece las leyes físicas del mundo real, volviéndose incontrolables e impredecibles. Ante la imposibilidad de poder establecer una relación con ellos con las características etológicas y ecológicas conocidas hasta este momento, es necesario realizar un cambio en tales relaciones, las cuales se reorganizan a una escala específicamente antropológica. Este subjetivo fenómeno se conoce como inversión antropológica (Bueno 1991), significando que la relación con estas entidades o seres siguen modelos típicamente humanos, con lo que se convierten en númenes o divinidades relacionadas con la naturaleza y los humanos que en ella viven (Alvargonzález 2005), en este particular caso en númenes paleolíticos.

La inversión antropológica, o formas análogas de conducta humana (p. e. personificación), pudieron ser un intento de relacionarse con tales seres utilizando los medios conocidos (comunicación verbal o simbólica entre humanos). Si estos númenes no se trataran desde un prisma antropológico, difícilmente se podría realizar una relación con ellos, pues sólo son posibles las relaciones entre humanos, con características psicobiológicas semejantes. Igualmente, las propias características de los elementos de la naturaleza (inexplicables, frecuentemente agresivos e imposibles de controlar) poseen unos aspectos difíciles de comprender y de asumir. Su control pasaría por la mediación de sus respectivos númenes paleolíticos, por medio de rituales idóneos.

Cualquiera de las figuras descritas por la etnografía para establecer las relaciones con esos númenes (brujo, chamán, hechicero, etc.) le otorga unas caracteristicas infundadas para su aplicación a las sociedades paleolíticas. Ante esta dificultad parece que el término mediadores paleolíticos podría ser adecuado, pues en su indefinición sólo señala la única cualidad que con seguridad podemos otorgarles. Estos mediadores podrían haberse materializado en las representaciones de teriántropos (figuras mixtas de humanos y animales), tan características del arte paleolítico. 0 , tal vez, los teriántropos sean la representación de algunos númenes, particularmente antropomorfizados por la inversión antropológica, con los que comunicarse directamente. En cualquier caso, estos seres que surgen en los estados alterados de conciencia están en el origen de los dioses y la religión, entendida como "religación de los hombres con los númenes" (Bueno 1996). Ambas posibilidades, manejadas por los clásicos de la Filosofía de la Religión, encajan en los límites del estructuralismo funcional y nos permiten formular hipótesis sobre el origen de las conductas espirituales y religiosas y su reflejo en el registro arqueológico conocido. 
La religión es, sin duda, la manifestación más expresiva del simbolismo humano como construcción colectiva. Se ha descrito un proceso evolutivo para la misma en tres grandes etapas, relacionando éstas con el desarrollo histórico y cultural de la humanidad. Las más antiguas, que aquí nos interesan especialmente, son las religiones primarias, asociadas al Paleolítico por cuanto se producen en sociedades cazadoras recolectoras y tienen su esencia en la relación numinosa con los animales; las religiones secundarias tienen un carácter mitológico y las terciarias metafísico (Bueno 1996). Nos referiremos solamente a las primeras. Pues bien, también podemos establecer un proceso con diversos estadios intermedios para alcanzar la religión primaria desde la conducta espiritual, pero no religiosa.

El primer estadio, en nuestro esquema, corresponde al simbolismo moderno elaborado, con conductas espirituales protoreligiosas, en el que aparece la percepción de la existencia de otros seres de características inmateriales, cuya existencia no traspasa la realidad del concepto creado por los seres humanos. Sólo serían reales en la mente de sus creadores y de los que creyeran en su existencia, y al surgir de los estados alterados de conciencia tendrían las características que tales entes tuvieran en estas alucinaciones, sueños o visiones. Los intentos de comunicación con los mismos se realizan por medio del proceso de inversión antropológica, o por la simple personificación de los númenes. Así, estos entes inmateriales adquiririan las cualidades que se conocen de los seres humanos y animales del mundo material, cotidiano, aunque en un grado mayor y/o diferente al conocido en el mundo real. Tras su conocimiento y aceptación social se producirian las interpretaciones que la sociedad o parte de ella realizaran sobre sus caracteristicas, utilidad y formas de relación. En definitiva, es la conversión de lo zoológico y etológico en específicamente antropológico, que debe poder ser explicado y narrado, con lo que pasa de la dimensión individual a la social (Alvargonzález 2005). Esta necesidad de explicación y manifestación social pudo pasar por una simbolización visual, sonora y conductual que podemos inferir del registro arqueológico y de las que sólo podemos mostrar algunas simbolizaciones plásticas, como son, fundamentalmente, una parte de las pinturas, grabados y estatuillas paleolíticas, instrumentos musicales y enterramientos con ofrendas ritualizadas que conocemos en la actualidad. Probablemente existió una literatura oral, en forma de relatos o canciones que tuvo un papel determinante en la socialización de estos conceptos, como muestra hoy la etnografía en comunidades de cazadores recolectores, pero esas manifestaciones no han fosilizado en el registro arqueológico.

Estas conductas simbólicas espirituales son el camino para la creación de un simbolismo religioso tras diversos estadios intermedios. Para su emergencia sería necesaria la adquisición de otros conceptos simbólicos socialmente aceptados y debidamente ritualizados, que asociados al primero (simplemente espiritual) conformarian las caracteristicas conductuales pro- pias de una religión que se puede definir como primaria. Por tanto, una conducta religiosa sería aquella que partiendo de las características anteriormente comentadas sobre las conductas espirituales, ha establecido algún tipo de relación organizada entre los dos mundos (material e inmaterial), debidamente protocolizada, y que tendrá repercusiones en el comportamiento de los individuos y de los grupos humanos. La conducta religiosa, por el carácter acumulativo descrito en los desarrollos cognitivos emergentes, engloba a la espiritual, pero no al contrario. El desarrollo de estas conductas sugiere la posibilidad de tener acceso al mundo espiritual, lo que podría ocurrir tras la muerte, lo que se justifica arqueológicamente con los enterramientos ritualizados de forma compleja, constituyendo lo que podríamos llamar religión en un amplio sentido. En realidad, no deja de ser una serie de estados intermedios de desarroIlo simbólico que no se produce con un carácter general, sino solamente en las áreas donde se han creado las condiciones suficientes y necesarias para ello. El comportamiento humano es territorial, de ahí la importancia de la dimensión regional en los estudios paleolíticos (Gamble 1984, 1990; Malmberg 1980; Menéndez 2012) para la identificación y señalamiento de esta transformación. Alli donde aparece supone la consecución del estadio superior del simbolismo moderno elaborado, con una conducta religiosa estructurada y una religión cuyo "corpus doctrinal" va enriqueciéndose progresivamente. Veamos brevemente los marcadores arqueológicos del proceso, singularmente de los estadios III y IV del Simbolismo moderno en Europa, que forman el núcleo de este trabajo.

\section{ARQUEOLOGÍA DEL SIMBOLISMO}

El pensamiento simbólico no fosiliza, pero algunas de sus manifestaciones sí lo hacen. Su presencia en el registro arqueológico se puede rastrear en los indicadores del manejo de las variables espacio y tiempo (territorialidad y capacidad de previsión); en las manifestaciones de individualidad (personal y social); en el imaginario de las manifestaciones plásticas (mobiliares y parietales) y en el contexto en el que aparecen; finalmente, en la presencia de comportamientos ritualizados sobre aspectos determinantes para los individuos y el grupo como son el sexo, la supervivencia y, sobre todo, la muerte. Asumiendo lo anteriormente expuesto y desde el modelo de análisis que nos brinda el estructuralismo funcional, vamos a centrarnos fundamentalmente en el paleolítico europeo entre 50.000 y 25.000 BP. Es decir, repasaremos los datos del Musteriense tardío, el Auriñaciense y Gravetiense, además de algunas de las Ilamadas culturas transicionales (Chatelperroniense, Uluzziense, Bohuniciense, etc.). Desgraciadamente no es mucha la información existente $y$, sobre todo, es de un valor científico muy desigual. No obstante, en los últimos años desde la arqueología y desde otras muchas disciplinas se han aportado datos de gran solidez científica 
que permiten formular hipótesis explicativas sobre el proceso emergente del simbolismo humano moderno.

Esos datos que podemos rastrear en el registro arqueológico se corresponden bastante bien con aquellos que podemos suponer que formaron parte del espectro onírico o alucinógeno que facilitó el descubrimiento del mundo que hemos definido como inmaterial: subsistencia, sexo, peligro, mediadores paleolíticos, manos y signos. El primero comprendería a los animales asequibles de caza, principalmente herbívoros, no peligrosos y potencialmente objeto de sus intereses logísticos o etológicos desconocidos. El segundo quedaría compuesto por una de las motivaciones básicas de la conducta humana: la sexual. El tercero se compondría por otra serie de animales peligrosos en la vida real, productores de miedos conscientes e inconscientes en la especie humana. Los teriántropos (humanos bestializados, generalmente mediante cuernos o una cabeza de animal) como elementos mediadores entre los dos mundos, que podrían ser humanos específicos en esa tarea o númenes muy antropomorfizados (esbozo de dioses) que enlazarían con los númenes de los animales. Las manos como componentes sociales, personales y espirituales que pueden variar según su ubicación. Y finalmente, los escasos signos de estos periodos, cuya sintaxis se nos escapa pero que pudieron estar relacionados con cualquiera de los campos anteriores como elementos de señalización y/o ubicación; claramente con el sexo en muchas ocasiones, pero también con los animales peligrosos, tal vez como númenes protectores de ciertos temores; o con los animales supuestamente logísticos, según las interpretaciones tradicionales del arte paleolítico. La ubicación de alguno de estos temas iniciales respecto al hábitat pudo ser muy relevante. No reciben el mismo tratamiento todas las obras del muy diverso arte paleolítico y parece razonable suponer diferente motivación y significación al arte permanentemente accesible y presente en lo cotidiano, respecto a aquel otro mucho menos asequible que se oculta en la profundidad de la cueva (Menéndez 1994). Abandonadas en la actualidad las opiniones de Laming-Emperaire y LeroiGourham sobre el desplazamiento hacia el interior de la cueva del arte rupestre con un sentido general y cronológico, sobre todo desde el descubrimiento del riquísimo arte parietal al aire libre de la cuenca del Duero, aún mantienen validez algunas de las afirmaciones de la primera, respecto a los comienzos del arte, en el sentido de que las obras exteriores e interiores no sólo tienen contenidos diferentes, sino que responden a motivaciones igualmente diferentes, a otro tipo de ceremonias "... acompañadas de otros cantos y otros relatos" (Laming-Emperaire 1962).

Aunque la resolución gráfica haya ido perfeccionándose con el paso del tiempo y el desarrollo de un mayor y mejor "oficio", el arte manifiesta desde su nacimiento los dos campos fundamentales en que es posible su realización: el realismo y la abstracción. Ambos fueron necesarios para explicar, con las dificultades de un lenguaje que debía acor- dar los términos para expresar esta realidad emergente y poner imágenes explicativas a un simbolismo tan complejo como los conceptos de la identidad, la propiedad o derecho de uso, el sexo, la reproducción y la supervivencia, el miedo o los númenes paleolíticos. Y seguramente otros muchos que desconocemos.

\subsection{Los adornos personales}

Los adornos personales constituyen la forma de representación más clara del desarrollo de la individualidad personal (autoconciencia) y social, realizados por medio de colgantes y pinturas en las personas y/o en sus vestimentas. Están formados por elementos cotidianos o exóticos, sin una clara utilidad instrumental, pero que por su forma, color, estructura y combinaciones Ilamarian la atención sobre el que los lleva, marcando cierta diferencia (convencionalismos) con los que no los poseen. Su variedad y complejidad son proporcionales a la diversidad social y al aumento de las desigualdades dentro del grupo, a la jerarquización de los individuos y al desarrollo de la competitividad (Hayden 1992; White 1993). Además de esa capacidad individualizadora, el adorno pone imágenes al símbolo y asi el signo se transforma en idea que, además, se puede reproducir casi infinitamente de formas diversas sin desvirtuar el código de valores más o menos efímeros o permanentes que muestra (Taborin 2004a y b).

El inicio de su producción estaría condicionado al desarrollo cognitivo y emergente de un nivel suficiente de autoconciencia e individualidad (social y personal), lo que sólo puede ocurrir cuando las condiciones socioeconómicas, lingüísticas, tecnológicas y ambientales, actuando en conjunto, formen un medio ambiente adecuado para tal fin, como hemos visto. Sabemos que estas circunstancias se produjeron en Blombos Cave, asociadas a HAM, hace al menos $70 \mathrm{Ky}$ (Hensihlwood et al. 2004). También se han encontrado en otros lugares conchas perforadas. Sería el caso de Argelia en el yacimiento de Djbban (Vanhaeren y D'Errico 2006) y en Taforal, Marruecos (Bouzouggar et al. 2007), por las misma fechas, más o menos; y de los procedentes del conocido yacimiento israelí de Skhul, con dos conchas perforadas entre los restos de las antiguas excavaciones y se han asignado a una horquilla cronológica similar y a HAM (Vanhaeren y D'Errico 2006). Sin embargo, desde hace algún tiempo existe un debate científico sobre la posibilidad de que HN también hubiera creado estas condiciones en el occidente de Europa o que se hubieran "aculturado" con los anteriores en las Ilamadas culturas transicionales. Incluso que los adornos asociados a neandertal pertenecieran a niveles auriñacienses revueltos, como pudiera ser el caso de la famosa colección mobiliar de la Grotte du Renne (Arcy) (p. e. Higham et al. 2010). Sin embargo, recientes hallazgos en el sureste de España, en la comunidad de Murcia, muestran la existencia de adornos consistentes en conchas perforadas con restos 
de colorantes artificiales, datados hacia 50.000 BP. en la Cueva de los Aviones y Cueva Antón (Zilhâo et al. 2010), así como numerosos restos de colorantes, quizá para su uso como pintura corporal. Podría citarse algún otro ejemplo, como el colgante de Lezetxiky (Arrizabalaga 2006). También el hallazgo de asociaciones de aves de plumajes vistosos, pero sin interés gastronómico, y los análisis tafonómicos de sus huesos, en Grota de Fumane, Italia, hacia 44.000 BP (Peresani et al. 2011), evidencian la existencia de otros adornos perecederos entre los HN del Musteriense. Por tanto en la actualidad sabemos que tanto HAM en África primero y en Europa después, crearon las condiciones necesarias, el nicho cognitivo adecuado, para la fabricación y el uso de adornos personales, con lo que esto implica. Pero también lo hicieron de forma independiente los HN tardíos europeos, antes de la llegada al continente de los HAM, aunque puedan jerarquizarse ambas manifestaciones en cuanto a su complejidad técnica y de diseño, así como a su volumen numérico o a la generalización de su uso.

Los adornos personales colgantes realizados sobre conchas de moluscos y dientes animales, y seguramente otros perecederos, aparecen a finales del Musteriense en Europa y se incrementan durante las Ilamadas culturas transicionales (Chatelperroniense, Uluzziense). Paradójicamente, hasta la fecha no se han localizado en los principales yacimientos musterienses meridionales de las Ilamadas "zonas refugio" del continente europeo, las penínsulas ibérica, itálica y balcánica, algunos con perduraciones hasta al menos $28 \mathrm{Ky}$ Tampoco aparecen en los yacimientos musterienses anteriores a $50 \mathrm{Ky}$ Por tanto, con los datos disponibles en la actualidad, parece que los neandertales fabricaron y usaron adornos corporales en el tramo final de su existencia, aunque el registro que han dejado es escaso; técnicamente están poco elaborados, utilizando como materia prima preferentemente objetos del entorno inmediato y no aparecen en ningún caso en contextos funerarios.

En el registro auriñaciense, en general, destacan los dientes perforados o ranurados para colgar, y las conchas marinas importadas en ocasiones desde costas muy lejanas (Taborin 1993; Álvarez 2006; Mellars 2006), así como las perlas de marfil. Existen diversos tipos y materias primas en su producción (conchas, marfil, asta, hueso, diversos tipos de piedra y fósiles) todos ellos preparados para colgar del portador o de sus vestidos (White 1993). Se han descrito hasta 158 tipos diferentes de adornos en 98 yacimientos pertenecientes al Auriñaciense (Vanhaeren y D'Errico 2006; Zilhäo 2007). Su abundancia, extensión, variedad y la compleja tecnología en su elaboración son claros exponentes del dominio de las técnicas del trabajo de materias primas óseas, muy poco utilizadas por los neandertales, y ahora de un uso más generalizado. Desconocemos si pudieron aparecer en contextos funerarios ya que no se han conservado enterramientos suficientemente bien documentados de este periodo en Europa.
Durante el Gravetiense, desde aproximadamente $28 \mathrm{Ky}$, aunque la tipología básica de adornos no cambia, se observa una mayor complejidad técnica, sobre todo en los adornos compuestos de múltiples piezas, que suponen una importante inversión de tiempo y energía. Aparecen asociados a contextos funerarios como los encontrados en los enterramientos de Grimaldi, donde apareció un bonete con 3.000 conchas; o en Sungir, con un complejo ajuar, lo que hace pensar que se formaban parte de los vestidos de los cadáveres (Bader 1978; Bader y Lavrushin 1998; Formicola 2007; Gamble 2001). Las conchas se obtienen de muy lejos (hasta $700 \mathrm{~km}$ ), continuando y ampliando la tradición auriñaciense, que ahora se incrementa con la presencia de otros objetos mobiliares que pudieran mostrar la existencia de redes de intercambio a larga distancia (White 1993; Gamble 2001).

En resumen, si la emergencia cognitiva que supone la aparición de la individualidad social y personal en contextos de hábitat, relacionados con actividades cotidianas, tiene uno de sus marcadores en la existencia de adornos personales, podemos proponer que ésta aparece en algunos grupos de los últimos neandertales en Europa. Con anterioridad se había mostrado en África, y llega a Europa con HAM asociado a contextos culturales auriñacienses. Esto constituye indudablemente una muestra de capacidad de simbolización, que situamos en el nivel de simbolismo moderno básico, no alcanzando el rango superior hasta que estos adornos no aparezcan en contextos simbólicos elaborados, ritualizados según modelos espirituales o religiosos, como los complejos enterramientos gravetienses.

\subsection{Los primeros enterramientos}

El reconocimiento objetivo de la muerte forma parte de un proceso cognitivo exclusivamente humano que no aparece ni entre los primates más evolucionados, como el chimpancé (Morin 1970; Goodal 1972). Va asociado a determinadas prácticas ritualizadas que oscilan entre la simple ocultación de los cadáveres hasta el reconocimiento de la muerte como un tránsito a otra dimensión vital, con numerosas variantes y estadios intermedios. Su manifestación arqueológica más importante son los enterramientos, que aquí nos interesan como parte sustancial de las conductas simbólicas humanas, aunque no sean las únicas relacionadas con la muerte. Se ha descrito como una forma de enterramiento deliberado el hallazgo de más de una treintena de individuos en la Sima de los Huesos, Atapuerca. Estos fósiles, asignados todos ellos al tipo $H$. heidelbergensis y datados en 400 Ky están acompañados de un bifaz de cuarcita interpretado como ofrenda funeraria (Carbonell y Mosquera 2006). Hasta el momento pueden constituir la muestra más antigua de "enterramiento" intencionado, aunque no todos los especialistas admitan esta última cualidad (Aguirre 2000). Los primeros enterramientos claramente intencionados, co- 
rresponden a HAM en África y Próximo Oriente, desde hace unos 100.000 años, asociados a la MSA en África y a una industria de lascas, de tipo musteriense, en Asia. Desde unas fechas parecidas, pero con claridad desde 70 Ky también los neandertales entierran intencionadamente a sus muertos en Europa y Próximo Oriente (Defleur 1993; Rivera 2010). Finalmente, en la horquilla temporal que constituye el núcleo central de este trabajo (50/25 Ky) encontramos en Europa algunos enterramientos musterienses y chatelperronienses de neandertales, así como pocos y dudosos restos funerarios auriñacienses; y un cambio sustancial con las elaboradas inhumaciones gravetienses, acompañadas de riquísimos ajuares, sobre todo en su variante oriental (Abramova 1995). Veamos cómo se produce este proceso de creciente complejidad técnica y formal, así como su interpretación simbólica.

En el yacimiento de Sima de los Huesos no ha podido determinarse, hasta la fecha, un patrón o modelo de enterramiento. Los cadáveres son transportados hasta Cueva
Mayor y arrojados a la Sima de los Huesos. Los restos humanos de más de treinta individuos (NMI) no presentan ni marcas de cortes susceptibles de ser interpretadas como rituales, ni fueron canibalizados previamente $y$, salvo el citado bifaz, no aparecen ajuares funerarios, ofrendas, fosas, hogares, etc. como componentes de ritos ad hoc. Por tanto, pudo existir un comportamiento funerario simple, de simbolismo inconsciente, que responde a la emergencia cognitiva de la individualidad social del grupo humano frente a otras especies animales y/o grupos humanos, pero sin huellas de individualidad personal o conductas espirituales. Así, este ocultamiento de los cadáveres, mejor que enterramiento, documentado aquí por primera vez en el registro arqueológico, muestra la emergencia del simbolismo en su nivel primitivo, el segundo más bajo de la escala que hemos propuesto.

Se conocen una cuarentena de posibles enterramientos neandertales (Cuadro 5). Su valor científico es desigual, incluso discutible en algunos de ellos su intencionalidad

Cuadro 5. Yacimientos musterienses con enterramientos atribuidos a los neandertales en Europa y el Próximo Oriente.

\begin{tabular}{|c|c|c|c|c|c|}
\hline $\begin{array}{l}\text { Yacimientos } \\
\text { País }\end{array}$ & $\begin{array}{c}\text { Sexo. Edad. } \\
\text { Patología. Tumba }\end{array}$ & Elementos asociados & $\begin{array}{l}\text { Características } \\
\text { sociales }\end{array}$ & $\begin{array}{c}\text { Cronología } \\
\text { aproximada BP }\end{array}$ & Referencias \\
\hline $\begin{array}{l}1 \text { Chapell aux } \\
\text { Saints (Francia) }\end{array}$ & $\begin{array}{l}\text { Adulto. No. } \\
\text { Cueva. Fosa }\end{array}$ & $\begin{array}{l}\text { Útiles. Huesos de } \\
\text { animales } \\
\text { fragmentados }\end{array}$ & $\begin{array}{c}\text { Musteriense tipo } \\
\text { Quina. Yacimiento } \\
\text { de alta densidad } \\
\text { y duración }\end{array}$ & \begin{tabular}{|c|} 
Cronoestratigrafía \\
$65-55000$ \\
REE: $46800 \pm 3200$ \\
$55800 \pm 4200$ \\
\end{tabular} & \multirow{9}{*}{$\begin{array}{l}\text { Binant, 1991; } \\
\text { Grün y Stringer, 1991; } \\
\text { Riel-Salvatore y Clark, } \\
2001 ; \\
\text { Trinkaus y Zilhäo, } 2002\end{array}$} \\
\hline $\begin{array}{l}2 \text { La Ferrasie } 1 \\
\text { (Francia) }\end{array}$ & $\begin{array}{l}\text { đodulto. No. } \\
\text { Abrigo. Fosa. Losas } \\
\text { en la cabeza }\end{array}$ & $\begin{array}{c}\text { Pocos útiles. Huesos } \\
\text { animales rotos. Cuerpo } \\
\text { sobre fuego }\end{array}$ & \multirow{8}{*}{$\begin{array}{l}\text { Asentamiento de } \\
\text { alta densidad y } \\
\text { duradero. Lugar } \\
\text { estratégico. } \\
\text { Musteriense tipo La } \\
\text { Ferrasie. } \\
\text { Alta densidad } \\
\text { poblacional (W } \\
\text { Europa) }\end{array}$} & \multirow{8}{*}{$\begin{array}{c}\text { Cronoestratigrafía } \\
75-60000\end{array}$} & \\
\hline $\begin{array}{l}3 \text { La Ferrasie } 2 \\
\text { (Francia) }\end{array}$ & $\begin{array}{l}\text { } \text { Adulto. No. } \\
\text { Abrigo. Fosa }\end{array}$ & $\begin{array}{l}\text { Asociado a útiles y } \\
\text { restos de animales } \\
\text { calcinados }\end{array}$ & & & \\
\hline $\begin{array}{l}4 \text { La Ferrasie } 3 \\
\text { (Francia) }\end{array}$ & $\begin{array}{l}\text { Niño 5-7 a. No. } \\
\text { Abrigo. Fosa } \\
\text { semiesférica }\end{array}$ & $\begin{array}{l}\text { Útiles. Huesos rotos } \\
\text { Fosa encima de fuego. } \\
\text { Pozos cercanos }\end{array}$ & & & \\
\hline $\begin{array}{c}5 \text { La Ferrasie 4a } \\
\text { (Francia) }\end{array}$ & $\begin{array}{l}\text { Feto. No. Abrigo. } \\
\text { Fosa }\end{array}$ & Útiles & & & \\
\hline $\begin{array}{c}6 \text { La Ferrasie } 4 b \\
\text { (Francia) }\end{array}$ & $\begin{array}{l}\text { Niño } 1 \text { mes. No. } \\
\text { Abrigo. Fosa }\end{array}$ & $\begin{array}{c}\text { Útiles } \\
\text { cerca de tres hoyos }\end{array}$ & & & \\
\hline $\begin{array}{l}7 \text { La Ferrasie } 5 \\
\text { (Francia) }\end{array}$ & $\begin{array}{l}\text { Feto. No. Abrigo. } \\
\text { Fosa. Montículo }\end{array}$ & $\begin{array}{c}\text { Mal conservado. Tres } \\
\text { raederas }\end{array}$ & & & \\
\hline $\begin{array}{l}8 \text { La Ferrasie } 6 \\
\text { (Francia) }\end{array}$ & $\begin{array}{l}\text { Niño 3-5 a. No. } \\
\text { Abrigo. Fosa con } \\
\text { losa triangular }\end{array}$ & $\begin{array}{c}\text { Sobre la tumba losa } \\
\text { con ahuecamientos en } \\
\text { su cara inferior }\end{array}$ & & & \\
\hline $\begin{array}{c}9 \text { La Ferrasie } 8 \\
\text { (Francia) }\end{array}$ & $\begin{array}{l}\text { Niño } 2 \text { años. No. } \\
\text { Abrigo }\end{array}$ & - & & & \\
\hline $\begin{array}{l}10 \text { Le Moustier } 1 \\
\text { (Francia) }\end{array}$ & $\begin{array}{l}\text { ô Joven. } 15 \text { a. No. } \\
\text { Abrigo }\end{array}$ & $\begin{array}{l}\text { Útiles. Restos de } \\
\text { huesos. "Almohada" } \\
\text { de piedra }\end{array}$ & \multirow{2}{*}{$\begin{array}{l}\text { Musteriense típico. } \\
\text { Alta densidad } \\
\text { poblacional } \\
\text { (W. Europa) }\end{array}$} & \multirow{2}{*}{$\begin{array}{l}\text { TL: } 40300 \pm 2600 \\
\quad 42600 \pm 3700\end{array}$} & \multirow{2}{*}{\begin{tabular}{|c|} 
Valladas et al., 1988; \\
Mellars, 1989; \\
Binant, 1991; \\
Riel-Salvatore y Clark, \\
2001
\end{tabular}} \\
\hline $\begin{array}{c}11 \text { Le Moustier } 2 \\
\text { (Francia) }\end{array}$ & $\begin{array}{l}\text { Niño } 2 \text { m. No. } \\
\text { Abrigo. Fosa }\end{array}$ & Útiles. Pozos cercanos & & & \\
\hline $\begin{array}{l}12 \text { La Quina } \\
\text { (Francia) }\end{array}$ & q Adulto. Abrigo. Sí & $\begin{array}{l}\text { Esferoide. Fragmentos } \\
\text { de hueso }\end{array}$ & $\begin{array}{l}\text { Musteriense tipo } \\
\text { Quina. Alta } \\
\text { densidad } \\
\text { poblacional } \\
\text { (W. Europa) }\end{array}$ & $\begin{array}{c}\text { Cronoestratigrafia } \\
65-55000 \\
\text { TL: } 43000 \pm 3600 \\
48750 \pm 6000\end{array}$ & $\begin{array}{c}\text { Binant, } 1991 \\
\text { Debenath y Jelinek, } \\
\text { 1998; Trinkaus } \\
\text { y Zilhao, } 2002\end{array}$ \\
\hline $\begin{array}{l}13 \text { Le Regourdou } \\
\text { (Francia) }\end{array}$ & $\begin{array}{l}\text { Adulto. Cueva. No. } \\
\text { Fosa. Túmulo }\end{array}$ & $\begin{array}{l}\text { Pocos útiles. Restos de } \\
\text { animales. Destacan los } \\
\text { de oso. Losas. Hogar }\end{array}$ & $\begin{array}{l}\text { Musteriense tipo. } \\
\text { Quina. Alta } \\
\text { densidad } \\
\text { poblacional } \\
\text { (W. Europa) }\end{array}$ & $\begin{array}{c}\text { Cronoestratigrafía } \\
65-55000\end{array}$ & $\begin{array}{c}\text { Binant, 1991; Trinkaus } \\
\text { y Zilhao, 2002; } \\
\text { Bonifay, 2008 }\end{array}$ \\
\hline
\end{tabular}




\begin{tabular}{|c|c|c|c|c|c|}
\hline $\begin{array}{l}\text { Yacimientos } \\
\text { País }\end{array}$ & $\begin{array}{c}\text { Sexo. Edad. } \\
\text { Patología. Tumba }\end{array}$ & Elementos asociados & $\begin{array}{l}\text { Características } \\
\text { sociales }\end{array}$ & $\begin{array}{c}\text { Cronología } \\
\text { aproximada BP }\end{array}$ & Referencias \\
\hline $\begin{array}{l}14 \text { Roc de Marsal } \\
\text { (Francia) }\end{array}$ & $\begin{array}{c}\text { Niño 2-10 a. Cueva. } \\
\text { No. Fosa }\end{array}$ & $\begin{array}{l}\text { Numerosos útiles y } \\
\text { restos de animales. } \\
\text { Sin estratigrafia }\end{array}$ & $\begin{array}{l}\text { Musteriense típico. } \\
\text { Alta densidad } \\
\text { poblacional } \\
\text { (W. Europa) }\end{array}$ & $\begin{array}{c}\text { Cronoestratigrafía } \\
\text { Sobre } 70000 \\
\text { ESR:76000 }\end{array}$ & $\begin{array}{c}\text { Madre-Dupouy, 1991; } \\
\text { Riel-Salvatore y Clark, } \\
\text { 2001; Trinkaus } \\
\text { y Zilhao, } 2002 \\
\end{array}$ \\
\hline $\begin{array}{l}15 \text { Spy } 1 \\
\text { (Bélgica) }\end{array}$ & $\begin{array}{l}\text { Odulto Cueva. No. } \\
\text { Sin estructura }\end{array}$ & $\begin{array}{c}\text { Abundantes } \\
\text { fragmentos de sílex }\end{array}$ & \multirow{2}{*}{$\begin{array}{l}\text { Musteriense tipo } \\
\text { Quina. Alta } \\
\text { densidad } \\
\text { poblacional } \\
\text { (W. Europa) }\end{array}$} & \multirow{2}{*}{$\begin{array}{c}\text { Cronoestratigrafía } \\
65-55000\end{array}$} & \multirow{2}{*}{$\begin{array}{c}\text { Riel-Salvatore y Clark, } \\
\text { 2001; Semal et al. } \\
\text { 2009; Trinkaus } \\
\text { y Zilhao, } 2002\end{array}$} \\
\hline $\begin{array}{l}16 \text { Spy } 2 \\
\text { (Bélgica) }\end{array}$ & $\begin{array}{c}\text { q Adolescente. No. } \\
\text { Cueva }\end{array}$ & $\begin{array}{l}\text { Punta musteriense. } \\
\text { Colmillos mamut }\end{array}$ & & & \\
\hline $\begin{array}{c}17 \text { Kiik Koba } 2 \\
\text { (Ucrania) }\end{array}$ & $\begin{array}{l}\text { Niño } 7 \text { m. Cueva. Sí. } \\
\text { Fosa profunda }\end{array}$ & \multirow{2}{*}{$\begin{array}{l}\text { Restos de animales } \\
\text { en la fosa y fuera }\end{array}$} & \multirow{2}{*}{$\begin{array}{c}\text { Musteriense de } \\
\text { tradición achelense } \\
\text { Nivel Vl }\end{array}$} & \multirow{2}{*}{$\begin{array}{c}\text { Cronoestratigrafía } \\
70-50000\end{array}$} & \multirow{2}{*}{$\begin{array}{c}\text { Binant, 1991; } \\
\text { Riel-Salvatore y Clark, } \\
\text { 2001; Trinkaus y } \\
\text { Zilhao, } 2002\end{array}$} \\
\hline $\begin{array}{c}18 \text { Kiik Koba } 12 \\
\text { (Ucrania) }\end{array}$ & $\begin{array}{l}\text { odulto. Cueva. } \\
\text { No. Fosa }\end{array}$ & & & & \\
\hline $\begin{array}{c}19 \text { Zaskalnaya } 1 \\
\text { (Ucrania) }\end{array}$ & $\begin{array}{l}\text { Niño } 1 \text { año. } \\
\text { Fosa }\end{array}$ & \multirow{3}{*}{ Enterramiento múltiple } & \multirow{3}{*}{$\begin{array}{l}\text { Micoquiense } \\
\text { oriental }\end{array}$} & \multirow{3}{*}{ C-14: 39000} & \multirow{3}{*}{ Trinkaus y Zilhao, 2002} \\
\hline $\begin{array}{c}20 \text { Zaskalnaya } 2 \\
\text { (Ucrania) }\end{array}$ & $\begin{array}{l}\text { Niño } 2-3 \text { años. } \\
\text { Fosa }\end{array}$ & & & & \\
\hline $\begin{array}{l}21 \text { Zaskalnaya } 3 \\
\text { (Ucrania) }\end{array}$ & $\begin{array}{l}\text { Niño 5-6 años. } \\
\text { Fosa }\end{array}$ & & & & \\
\hline $\begin{array}{c}22 \text { Mezmaiskaya } \\
1 \text { (Rusia) }\end{array}$ & $\begin{array}{l}\text { Niño } 1 \mathrm{~m} . \\
\text { Nivel } 3\end{array}$ & Enterramiento múltiple & $\begin{array}{l}\text { Micoquiense } \\
\text { oriental }\end{array}$ & $\begin{array}{l}\text { ESR: } 36200- \\
73000 \pm 500\end{array}$ & $\begin{array}{l}\text { Ovchinnikov } \\
\text { et al. 2000; Skinner } \\
\text { et al. } 2005\end{array}$ \\
\hline $\begin{array}{l}23 \text { Teshik Tash } \\
\text { (Uzbekistán) }\end{array}$ & $\begin{array}{l}\text { Niña 8-9 a. Cueva. } \\
\text { No. Fosa. Losas }\end{array}$ & $\begin{array}{c}\text { Circulo de } 6 \text { cuernas } \\
\text { de cabra. Cerca fuego, } \\
\text { numerosas raederas }\end{array}$ & $\begin{array}{l}\text { Musteriense. } \\
\text { Pequeña cueva }\end{array}$ & $\begin{array}{c}\text { Cronoestratigrafía } \\
70-35000 ?\end{array}$ & $\begin{array}{c}\text { Binant, 1991; } \\
\text { Riel-Salvatore y Clark, } \\
2001\end{array}$ \\
\hline $\begin{array}{c}24 \text { Kebara } 1 \\
\text { (Israel) }\end{array}$ & $\begin{array}{c}\text { Niño } 7 \text { meses. No. } \\
\text { Cueva }\end{array}$ & Útiles musterienses & \multirow{2}{*}{$\begin{array}{l}\text { Musteriense tipo } \\
\text { Tabun B. Alta } \\
\text { densidad } \\
\text { poblacional (P. O.) }\end{array}$} & \multirow{2}{*}{$\begin{array}{c}\text { TL: } 48300 \pm 3500 \\
61600 \pm 3600\end{array}$} & \multirow{2}{*}{$\begin{array}{c}\text { Riel-Salvatore y Clark, } \\
\text { 2001; } \\
\text { Trinkaus y Zilhao, } 2002\end{array}$} \\
\hline $\begin{array}{c}25 \text { Kebara } 2 \\
\text { (Israel) }\end{array}$ & $\begin{array}{l}\text { Adulto. No. } \\
\text { Cueva }\end{array}$ & $\begin{array}{c}\text { Hioides. Útiles } \\
\text { musterienses. Hogar }\end{array}$ & & & \\
\hline $\begin{array}{c}26 \text { Amud } 1 \\
\text { (Israel) }\end{array}$ & $\begin{array}{l}\text { Adulto. No. } \\
\text { Cueva }\end{array}$ & $\begin{array}{c}\text { Sin relación con los } \\
\text { útiles del yacimiento }\end{array}$ & \multirow{2}{*}{$\begin{array}{l}\text { Musteriense tipo } \\
\text { Tabun B. Alta } \\
\text { densidad } \\
\text { poblacional (P. O.) }\end{array}$} & \multirow{2}{*}{$\begin{array}{c}\text { REE: } 41500 \pm 3000 \\
49500 \pm 4000 \\
T L, \text { ESR: sobre los } \\
60-50000\end{array}$} & \multirow{2}{*}{$\begin{array}{l}\text { Grün y Stringer, 1991; } \\
\text { Rak et al. 1994; } \\
\text { Riel-Salvatore y Clark, } \\
\text { 2001; Trinkaus } \\
\text { y Zilhao, } 2002\end{array}$} \\
\hline $\begin{array}{l}27 \text { Amud } 7 \\
\text { (Israel) }\end{array}$ & $\begin{array}{l}\text { Niño } 10 \text { meses. No. } \\
\text { Cueva. Fosa }\end{array}$ & $\begin{array}{c}\text { Maxilar superior de } \\
\text { ciervo rojo en su pelvis }\end{array}$ & & & \\
\hline $\begin{array}{l}28 \text { Tabün } \\
\text { (Israel) }\end{array}$ & $\begin{array}{l}\text { o Adulto. No. } \\
\text { Cueva. Fosa }\end{array}$ & $\begin{array}{l}\text { Relacionado con } \\
\text { dientes mamífero }\end{array}$ & $\begin{array}{l}\text { Musteriense tipo } \\
\text { Tabun B. Alta } \\
\text { densidad } \\
\text { poblacional (P. O.) }\end{array}$ & Por TL 160000 & $\begin{array}{c}\text { Mercier et al. 2000; } \\
\text { Riel-Salvatore y Clark, } \\
2001\end{array}$ \\
\hline $\begin{array}{l}29 \text { Dederiyeh } 1 \\
\text { (Siria) }\end{array}$ & $\begin{array}{l}\text { Niño 1-3 años. No. } \\
\text { Cueva. Fosa }\end{array}$ & $\begin{array}{c}\text { Piedra triangular } \\
\text { sobre el tórax. Losa en } \\
\text { la cabeza }\end{array}$ & \multirow{2}{*}{$\begin{array}{c}\text { Musteriense tipo } \\
\text { Tabun B. Numerosos } \\
\text { restos de } \\
\text { neandertales }\end{array}$} & \multirow{2}{*}{ TL: 70-50000 } & \multirow{2}{*}{$\begin{array}{l}\text { Riel-Salvatore } \\
\text { y Clark, 2001; } \\
\text { Akazawa } \\
\text { y Muhesen, } 2003\end{array}$} \\
\hline $\begin{array}{l}30 \text { Dederiyeh } 2 \\
\text { (Siria) }\end{array}$ & $\begin{array}{l}\text { Niño. } 2 \text { años. No. } \\
\text { Cueva }\end{array}$ & - & & & \\
\hline $\begin{array}{c}31 \text { Shanidar } 1 \\
\text { (Irak) }\end{array}$ & $\begin{array}{l}\text { Adulto. No. } \\
\text { Cueva. Fosa }\end{array}$ & $\begin{array}{c}\text { Graves lesiones } \\
\text { con supervivencia }\end{array}$ & \multirow{7}{*}{$\begin{array}{c}\text { Musteriense. } \\
\text { Yacimiento de gran } \\
\text { potencia } \\
\text { estratigráfica } \\
(14 \text { m), de larga } \\
\text { duración }\end{array}$} & \multirow{2}{*}{$\begin{array}{c}\text { Cronoestratigrafía } \\
70-35000 ; C-14: \\
46900 \pm 1500 \\
50000 \pm 3000\end{array}$} & \multirow{7}{*}{$\begin{array}{c}\text { Bar-Yosef, 1989; } \\
\text { Riel-Salvatore } \\
\text { y Clark, 2001; } \\
\text { Trinkaus y Zilhao, } 2002\end{array}$} \\
\hline $\begin{array}{c}32 \text { Shanidar } 3 \\
\text { (Irak) }\end{array}$ & $\begin{array}{c}\text { Adulto. Si. Cueva. } \\
\text { Fosa }\end{array}$ & - & & & \\
\hline $\begin{array}{l}33 \text { Shanidar } 4 \\
\text { (Irak) }\end{array}$ & $\begin{array}{l}\text { Adulto. No. } \\
\text { Cueva. Fosa }\end{array}$ & Polen de flores & & \multirow{5}{*}{$\begin{array}{c}\text { Por anatomía } \\
120-90000\end{array}$} & \\
\hline $\begin{array}{l}34 \text { Shanidar } 6 \\
\text { (Irak) }\end{array}$ & $\begin{array}{l}\text { Adulto. No. } \\
\text { Cueva }\end{array}$ & - & & & \\
\hline $\begin{array}{c}35 \text { Shanidar } 7 \\
\text { (Irak) }\end{array}$ & $\begin{array}{c}\text { Niño } 9 \text { meses. No. } \\
\text { Cueva }\end{array}$ & Hogar & & & \\
\hline $\begin{array}{c}36 \text { Shanidar } 8 \\
\text { (Irak) }\end{array}$ & $\begin{array}{l}\text { Adulto. No. } \\
\text { Cueva }\end{array}$ & - & & & \\
\hline $\begin{array}{l}37 \text { Shanidar } 9 \\
\text { (Irak) }\end{array}$ & $\begin{array}{c}\text { Niño } 9 \text { meses. No. } \\
\text { Cueva }\end{array}$ & Enterramiento múltiple & & & \\
\hline
\end{tabular}


funeraria, y su reaparto cronológico y geográfico está muy descompensado respecto al desarrollo histórico de esta especie. Pero antes de comentar estos datos es pertinente constatar que frente a la discusión clásica de los componentes simbólicos que pudieron motivar estos comportamientos, incluso la negación del carácter intencionado de tales enterramientos (Gargett 1989, 1999), existen otras prácticas funerarias que pudieran vincularse a la emergencia de un simbolismo moderno, tales como la presencia de cortes de apariencia ritual (Kaprina o Combe Grenal 3) o desmembramientos, que aparecen en restos que no fueron sepultados pero que pudieron formar parte de otros comportamientos funerarios, tales como el canibalismo ritual o el enterramiento en dos tiempos (Giacobini 2006; Garralda 2008), independientemente del canibalismo alimentario, bien documentado en numerosos yacimientos del Paleolítico medio (Cuadro 6).
El conjunto de enterramientos neandertales que analizamos, cuando es posible su identificación, muestra 17 adultos (12 hombres y 4 mujeres), dos jóvenes y 20 niños, incluyendo 4 fetos y neonatos. Inmediatamente llama la atención el alto número de restos infantiles, presentes en todas las áreas, y mayoritarios en los yacimientos de Europa oriental. También su desigual reparto geográfico, concentrándose en un área francesa (Aquitania), Próximo Oriente (Israel, Siria e Irak) y, en menor medida, en Ucrania. Todos aparecen en contextos musterienses, o paramusterienses, como en Saint-Cesaire (Chatelperroniense) y Zaskalnaya y Mezmaiskaya (Micoquiense oriental). No es fácil hacer agrupamientos cronológicos, pues existen muchas dataciones contradictorias en función del método empleado y la época en que se realizaron las excavaciones. Sin embargo se observa que, dentro de la simplicidad general de gestos funerarios, son más claros y elaborados los que se inscriben en la

Cuadro 6. Yacimientos musterienses con posibilidades de antropofagia entre los neandertales en Europa.

\begin{tabular}{|c|c|c|c|c|}
\hline $\begin{array}{l}\text { Yacimientos } \\
\text { País }\end{array}$ & Lugar. Número. Edad. & Características & $\begin{array}{c}\text { Cronología } \\
\text { aproximada BP }\end{array}$ & Referencias \\
\hline $\begin{array}{l}\text { 1. Krapina } \\
\text { (Croacia) }\end{array}$ & $\begin{array}{l}\text { Abrigo. } 711 \text { restos de unos } 80 \\
\text { individuos mezclados con } \\
\text { huesos de animales y útiles } \\
\text { musterienses. } 64 \% \text { infantiles }\end{array}$ & $\begin{array}{l}\text { Restos humanos con marcas de } \\
\text { cortes, fracturas para extraer } \\
\text { medula y asociados al fuego }\end{array}$ & Sobre 130000 & $\begin{array}{c}\text { Russel, 1987; } \\
\text { Binant, 1991; } \\
\text { Montet-White, } 1996\end{array}$ \\
\hline 2. Vindija (Croacia) & $\begin{array}{l}\text { Cueva. Nivel G1: Fragmento } \\
\text { de mandibula y de parietal }\end{array}$ & $\begin{array}{l}\text { Huesos humanos con marcas } \\
\text { de corte }\end{array}$ & $\begin{array}{c}32400 \pm 800 \\
32400 \pm 1800\end{array}$ & Higham et al. 2006 \\
\hline $\begin{array}{l}\text { 3. El Sidrón } \\
\text { (España) }\end{array}$ & $\begin{array}{l}\text { Cueva. Restos } 6 \text { adultos, } \\
3 \text { juveniles y } 3 \text { infantiles }\end{array}$ & $\begin{array}{c}\text { Huesos humanos con marcas } \\
\text { de corte }\end{array}$ & Cir. 50.000 & $\begin{array}{l}\text { Rosas et al. } 2006 \\
\text { Rasilla et al. } 2012\end{array}$ \\
\hline $\begin{array}{l}\text { 4. Boquete } \\
\text { de Zafarraya } \\
\text { (España) }\end{array}$ & $\begin{array}{l}\text { Cueva. Restos de } 7 \text { individuos } \\
\text { adultos y } 2 \text { infantiles }\end{array}$ & $\begin{array}{c}\text { En los huesos humanos señales } \\
\text { de cortes con instrumentos } \\
\text { líticos }\end{array}$ & $\begin{array}{l}\text { U/Th: } 25100 \pm 1300 \\
33400 \pm 2000 \\
\text { C14: } 29800 \pm 600 \\
31800 \pm 550\end{array}$ & Hublin et al. 1995 \\
\hline $\begin{array}{l}\text { 5. Grotte de } \\
\text { I'Hortus (Francia) }\end{array}$ & $\begin{array}{l}\text { Cueva. Restos de entre } 20 \text { y } \\
36 \text { individuos ( } 6 \text { infantiles) }\end{array}$ & $\begin{array}{c}\text { Se encontraron junto con } \\
\text { osamentas de animales. } \\
\text { Marcas de corte }\end{array}$ & Musteriense típico & De Lumley, 1973 \\
\hline $\begin{array}{l}\text { 6. Moula-Guercy } \\
\text { (Francia) }\end{array}$ & $\begin{array}{l}\text { Cueva. En el nivel XV se } \\
\text { encontraron } 12 \text { fragmentos } \\
\text { de huesos de Neandertal }\end{array}$ & $\begin{array}{c}\text { Huesos mezclados de neandertal } \\
\text { y de animales con marcas } \\
\text { de corte }\end{array}$ & $\begin{array}{c}\text { Musteriense } \\
\text { Entre 100-125000 }\end{array}$ & Defleur et al. 1999 \\
\hline $\begin{array}{l}\text { 7. Combe Grenal } \\
\text { (Francia) }\end{array}$ & $\begin{array}{c}\text { Cueva. Nivel 25. Muchos } \\
\text { restos humanos dispersos y } \\
\text { fragmentados, mezclados con } \\
\text { huesos de animales y útiles } \\
\text { musterienses }\end{array}$ & $\begin{array}{l}\text { En una incompleta mandibula } \\
\text { juvenil y en un húmero } \\
\text { de adulto se reconocen marcas } \\
\text { de cortes }\end{array}$ & $\begin{array}{l}\text { Musteriense tipo } \\
\text { Quina. } \\
\text { Sobre } 75-65000\end{array}$ & Garralda et al. 2005 \\
\hline $\begin{array}{l}\text { 8. Marillac } \\
\text { (Francia) }\end{array}$ & $\begin{array}{c}\text { Cueva. Restos humanos en } \\
\text { los niveles } 9 \text { y } 10, \text { mezclados } \\
\text { con abundantes restos de } \\
\text { fauna y útiles }\end{array}$ & $\begin{array}{c}\text { En la parte posterior de un } \\
\text { neurocráneo de adulto se } \\
\text { encuentran varias marcas } \\
\text { de corte }\end{array}$ & Musteriense & Garralda et al. 2005 \\
\hline $\begin{array}{l}\text { 9. Macassargues } \\
\text { (Francia) }\end{array}$ & $\begin{array}{l}\text { Cueva. Restos óseos de joven } \\
\text { de } 13-14 \text { años }\end{array}$ & $\begin{array}{l}\text { Nivel 5, junto a un hogar. } \\
\text { Marcas de corte }\end{array}$ & $\begin{array}{l}\text { Musteriense típico } \\
\text { con denticulados }\end{array}$ & Le Mort, 1989 \\
\hline $\begin{array}{l}\text { 10. Les Pradelles } \\
\text { (Francia) }\end{array}$ & $\begin{array}{c}\text { Cueva. } 38 \text { fragmentos de } \\
\text { huesos de } 5 \text { neandertales, } \\
\text { junto con numerosos restos } \\
\text { de animales. }\end{array}$ & $\begin{array}{c}\text { Posible campamento de caza. } \\
\text { Marcas de corte en los huesos } \\
\text { de } 4 \text { neandertales }\end{array}$ & $\begin{array}{l}\text { Musteriense tipo } \\
\text { Quina }\end{array}$ & Mann, et al. 2005 \\
\hline $\begin{array}{l}\text { 11. Feldhofer } \\
\text { (Alemania) }\end{array}$ & Cueva. Adulto & Marcas de corte & $\begin{array}{c}\text { Micoquiense. } \\
\text { C-14: } 39900 \pm 620\end{array}$ & Schmitz et al. 2002 \\
\hline
\end{tabular}


shorquilla 70/50.000 BP que aquellos asignados a 50/35.000 BP. Estos gestos funerarios se resumen en la excavación de fosas para depositar el cadáver, con presencia de ocre rojo, losas para cubrirlo que ocasionalmente pueden presentar cazoletas talladas, polen de plantas o algunos restos animales interpretados como ofrendas, pozos $u$ hogares cercanos y algunos útiles, sobre todo raederas. No entraremos en la casuística concreta, por ser bien conocida (Cuadro 5) sino en las consideraciones generales que nos interesan.

Los enterramientos neandertales que hemos descrito resumidamente muestran un reconocimiento objetivo de la muerte durante el Paleolítico medio. También sugieren el desarrollo de sentimientos de bondad y compasión ante el enterramiento de ancianos que sobrevivieron a dolencias que hubieron de requerir la solidaridad del grupo (Shanidar 1) o los elaborados y frecuentes rituales funerarios con niños, incluso neonatos. Sin duda estos sentimientos forman parte de las emergencias cognitivas que caracterizan la conducta moderna, pero no hay elementos que permitan inferir una dimensión espiritual o, mucho menos religiosa, de estas prácticas funerarias. Frecuentemente se ha hecho una relación acrítica y abusiva del hecho de enterrar ritualmente a los muertos como formas de tránsito a otra vida (Vandermemeersch 2005). El reconocimiento objetivo de la muerte en sociedades que han desarrollado sentimientos de compasión y amor supone una situación traumática suficientemente importante como para darle un tratamiento específico al cadáver del difunto. Más acusada, sin duda, en casos de personalidades importantes para el grupo. Pero no observamos en el tratamiento de los restos humanos elementos claros de simbolismo social o jerárquico. Todo lo más de simbolismo emocional, sobre todo en los enterramientos infantiles.

En resumen, parece que los enterramientos neandertales responden a estados intermedios de evolución conductual camino de las que hemos definido como modernas básicas, lo que se confirma arqueológicamente con el posterior inicio de los adornos personales, como hemos visto. Estas conductas muestran una vía independiente en su origen y paralela en su evolución temporal a la de los HAM respecto al desarrollo cognitivo moderno. Pero no parece, a juzgar por los enterramientos conocidos hasta la fecha, que en el caso de los neandertales llegue a traspasarse el umbral de las conductas espirituales. Merece destacarse la mayor simplicidad o ausencia de enterramientos en las fases más próximas al Paleolítico superior o durante el mismo, en las Ilamadas zonas refugio del sur de Europa, hasta el 28.000 $\mathrm{BP}$, singularmente en la Península lbérica por lo numeroso de los hallazgos de diferentes tipos de hábitats y la ausencia de enterramientos, salvo los recientes de Sima de las Palomas, en Murcia, aunque se datan en 50 Ky (Walker et al. 2009). Durante los más de 10.000 años en que los neandertales musterienses tardíos y quizá los de las Ilamadas culturas transicionales comparten el continente europeo con los sapiens modernos no se han hallado enterramientos de los mismos, hasta la fecha. Solamente el dudoso enterramiento de la Roche a Pierrot, hacia $36.000 \mathrm{BP}$, sin rito funerario reconocible (Vandermeersch 1987). Pero esta situación es similar a la de los HAM del Auriñaciense, como veremos.

\subsection{Los enterramientos de HAM}

En África y Próximo Oriente se han documentado hasta 24 posibles enterramientos humanos intencionados (Cuadro 7) de HAM asociados a contextos del musteriense 0 de la MSA. La mayoría se sitúan en la horquilla cronológica 100/80.000 BP. Como en el caso de los neandertales analizado, hay un alto porcentaje de niños. Tampoco aparecen elementos individualizadores o adornos en las tumbas, salvo unas conchas perforadas en Skhül 5 y Border Cave. Por tanto, a juzgar por el registro arqueológico, los comportamientos funerarios no difieren mucho de los que hemos descrito para los neandertales, incluso parecen menos elaborados. $Y$ no puede afirmarse que este modelo funerario cambie con el Auriñaciense europeo. Como es sabido, los antiguos enterramientos atribuidos a esta cultura, como los de Cro-Magnon (Eyzies-de-Tayac) o Mladeç (Moravia del norte) han sido descartados en sus altas cronologías. Solamente podemos citar los pseudomorfos o moldes humanos hallados en el Auriñaciense arcaico de Cueva Morín (Cantabria). Su inmaterialidad solo permite formular hipótesis sobre la presencia de unas conductas funerarias simples hacia el $35 \mathrm{Ky}$ (González Echegaray y Freeman 1978).

La situación que hemos descrito cambiará radicalmente con el desarrollo del Gravetiense, hacia 30.000 BP. Algunos yacimientos de Europa central y oriental muestran un salto cualitativo en los comportamientos funerarios. Nuevas y variadas formas de enterramiento aparecen en Moravia (Rep. Checa), en tumbas individuales o colectivas, que se abren en cuevas o en los campamentos al aire libre, a veces recubiertas de huesos de mamut. Pero, sobre todo, acompañadas de un variado y rico ajuar compuesto por esculturas de animales o humanas, adornos, armas, etc. en marfil, hueso 0 barro cocido, según patrones de enterramiento muy complejos y estereotipados (posición del cadáver, o cadáveres, uso de ocre, etc.). En Dolni Vestinice, Brno, Predmosti o Pavlov desde 29.000 BP, vinculadas al Pavloviense, una variante del Gravetiense oriental. En Rusia, en un contexto cultural similar, debe citarse el conjunto de yacimientos de Kostienki (Abramova 1995; Djindjian et al. 1999; Gamble 2001). Allí se han localizado enterramientos con ricos ajuares, o estructuras fabricadas con huesos y colmillos de mamut, como el adulto de Kostienki XIV, hallado por debajo de un nivel cuya datación más alta llega a 28200 \pm 700 (LU59), asociado a un Gravetiense antiguo; o los niños de K. XVIII, 21020 180 BP (OxA7128) y K. XIV, enterrado con ocre, diversas piezas 
Cuadro 7. Yacimientos musterienses y del MSA con enterramientos atribuidos a los HAM en Próximo Oriente y África.

\begin{tabular}{|c|c|c|c|c|c|}
\hline $\begin{array}{l}\text { Yacimientos } \\
\text { País }\end{array}$ & $\begin{array}{c}\text { Sexo. Edad. } \\
\text { Patología. Tumba }\end{array}$ & Elementos asociados & $\begin{array}{l}\text { Características } \\
\text { sociales }\end{array}$ & $\begin{array}{c}\text { Cronología } \\
\text { aproximada BP }\end{array}$ & Referencias \\
\hline 1. Skhül 1 (Israel) & $\begin{array}{l}\text { Niño 4-6 años. Si. } \\
\text { Abrigo/Cueva. Fosa }\end{array}$ & Útiles & \multirow{10}{*}{$\begin{array}{l}\text { Los enterramientos } \\
\text { se realizan en } \\
\text { terrazas en frente } \\
\text { de las cuevas. } \\
\text { Musteriense tipo } \\
\text { Tabun C. } \\
\text { Yacimiento de gran } \\
\text { duración. } \\
\text { Importante } \\
\text { demografía y } \\
\text { relaciones sociales }\end{array}$} & \multirow{10}{*}{$\begin{array}{l}\text { REE: } 81000 \pm 15000 \\
T L: 101000 \pm 12000\end{array}$} & \multirow{10}{*}{$\begin{array}{c}\text { Grün y Stringer, 1991; } \\
\text { Mercier et al. 1993; } \\
\text { Riel-Salvatore } \\
\text { y Clark, 2001; } \\
\text { Trinkaus } \\
\text { y Zilhao, } 2002\end{array}$} \\
\hline 2. Skhül 2 (Israel) & $\begin{array}{c}\text { Adulto. No. } \\
\text { Abrigo/Cueva }\end{array}$ & - & & & \\
\hline 3. Skhül 3 (Israel) & $\begin{array}{c}\text { Adulto. No. } \\
\text { Abrigo/Cueva }\end{array}$ & - & & & \\
\hline 4. Skhül 4 (Israel) & $\begin{array}{c}\text { त Adulto. No. } \\
\text { Abrigo/Cueva. Fosa }\end{array}$ & Útiles & & & \\
\hline 5. Skhül 5 (Israel) & $\begin{array}{c}\text { đAdulto. No. } \\
\text { Abrigo/Cueva. Fosa }\end{array}$ & $\begin{array}{c}\text { Mandibula jabalí. } \\
\text { Conchas perforadas }\end{array}$ & & & \\
\hline 6. Skhül 6 (Israel) & $\begin{array}{l}\text { J Adulto. No. } \\
\text { Abrigo/Cueva }\end{array}$ & 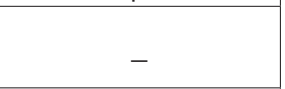 & & & \\
\hline 7. Skhül 7 (Israel) & $\begin{array}{l}\text { O Adulto. No. } \\
\text { Abrigo/Cueva }\end{array}$ & - & & & \\
\hline 8. Skhül 8 (Israel) & $\begin{array}{l}\text { Niño } 10 \text { años. } \\
\text { Abrigo/Cueva }\end{array}$ & - & & & \\
\hline 9. Skhül 9 (Israel) & $\begin{array}{l}\text { N Adulto. Si. } \\
\text { Abrigo/Cueva }\end{array}$ & - & & & \\
\hline $\begin{array}{l}\text { 10. Skhül } 10 \\
\text { (Israel) }\end{array}$ & $\begin{array}{l}\text { Niño 4-6 años. } \\
\text { Abrigo/Cueva }\end{array}$ & - & & & \\
\hline $\begin{array}{l}\text { 11. Qafzeh } 3 \\
\text { (Israel) }\end{array}$ & $\begin{array}{l}\text { क Adulto. No. } \\
\text { Cueva }\end{array}$ & - & \multirow{11}{*}{$\begin{array}{l}\text { Los enterramientos } \\
\text { se realizan en } \\
\text { terrazas en frente } \\
\text { de las cuevas. } \\
\text { Musteriense tipo } \\
\text { Tabun C. } \\
\text { Yacimiento de gran } \\
\text { duración. } \\
\text { Importante } \\
\text { demografía y } \\
\text { relaciones sociales. }\end{array}$} & \multirow{11}{*}{$\begin{array}{c}\text { TL: } 92000 \pm 5000 \\
\text { REE: } 100000 \pm 10000 \\
120000 \pm 8000\end{array}$} & \multirow{11}{*}{$\begin{array}{c}\text { Valladas et al. 1988; } \\
\text { Grün y Stringer, 1991; } \\
\text { Riel-Salvatore } \\
\text { y Clark, 2001; } \\
\text { Trinkaus } \\
\text { y Zilhao, } 2002\end{array}$} \\
\hline $\begin{array}{l}\text { 12. Oafzeh } 6 \\
\text { (Israel) }\end{array}$ & $\begin{array}{l}\text { Adulto. } \\
\text { Cueva }\end{array}$ & - & & & \\
\hline $\begin{array}{l}\text { 13. Qafzeh } 7 \\
\text { (Israel) }\end{array}$ & $\begin{array}{l}\text { Adulto. } \\
\text { Cueva }\end{array}$ & - & & & \\
\hline $\begin{array}{l}\text { 14. Qafzeh } 8 \\
\text { (Israel) }\end{array}$ & $\begin{array}{l}\text { Adulto. No. } \\
\text { Cueva. Fosa }\end{array}$ & $\begin{array}{l}\text { Útiles. Ocre. Piedras } \\
\text { sobre el esqueleto }\end{array}$ & & & \\
\hline $\begin{array}{l}\text { 15. Qafzeh } 9 \\
\text { (Israel) }\end{array}$ & $\begin{array}{l}\text { O Adulto. Si. } \\
\text { Cueva. Fosa }\end{array}$ & $x_{1.25}$ & & & \\
\hline $\begin{array}{l}\text { 16. Qafzeh } 10 \\
\text { (Israel) }\end{array}$ & $\begin{array}{c}\text { Niño } 6 \text { años. No. } \\
\text { Cueva. Fosa }\end{array}$ & - & & & \\
\hline $\begin{array}{l}\text { 17. Qafzeh } 12 \\
\text { (Israel) }\end{array}$ & $\begin{array}{l}\text { Niño } 10 \text { años. No. } \\
\text { Cueva. Fosa }\end{array}$ & $\begin{array}{l}\text { Ocre? Fragmentos } \\
\text { de hueso. Piedras } \\
\text { sobre esqueleto }\end{array}$ & & & \\
\hline $\begin{array}{l}\text { 18. Qafzeh } 13 \\
\text { (Israel) }\end{array}$ & Feto. Cueva & - & & & \\
\hline $\begin{array}{l}\text { 19. Qafzeh } 15 \\
\text { (Israel) }\end{array}$ & $\begin{array}{c}\text { Niño 8-10 años. No. } \\
\text { Cueva. Fosa }\end{array}$ & - & & & \\
\hline $\begin{array}{l}\text { 20. Qafzeh } 21 \\
\text { (Israel) }\end{array}$ & $\begin{array}{l}\text { Niño } 3 \text { años. } \\
\text { Cueva }\end{array}$ & - & & & \\
\hline $\begin{array}{l}\text { 21. Qafzeh } 22 \\
\text { (Israel) }\end{array}$ & $\begin{array}{l}\text { Niño } 4-6 \text { años. } \\
\text { Cueva }\end{array}$ & - & & & \\
\hline $\begin{array}{l}\text { 22. Taramsa Hill } \\
\text { (Egipto) }\end{array}$ & $\begin{array}{c}\text { Niño 8-10 a. Pozo } \\
\text { de la cantera. } \\
\text { Montículo }\end{array}$ & $\begin{array}{l}\text { Abundantes útiles } \\
\quad \text { líticos. Final } \\
\text { Paleolítico Medio }\end{array}$ & $\begin{array}{c}\text { Cultura Levallois- } \\
\text { Musteriense. } \\
\text { No hábitat, cantera. }\end{array}$ & OSL: 80-50000 & $\begin{array}{l}\text { Vermeersch et al. } \\
\text { 1998; McBrearty y } \\
\text { Brooks, } 2000\end{array}$ \\
\hline $\begin{array}{l}\text { 23. Border Cave } \\
\text { (Sudáfrica) }\end{array}$ & $\begin{array}{l}\text { Cueva. Niño } \\
\text { flexionado }\end{array}$ & $\begin{array}{c}\text { Concha de Conus } \\
\text { africanus perforada } \\
\text { y ocre }\end{array}$ & $\begin{array}{c}\text { MSA } \\
\text { Hábitat de larga } \\
\text { duración. Relaciones } \\
\text { comerciales }\end{array}$ & $\begin{array}{l}\text { Entre 90-100000. } \\
\text { Por relación } \\
\text { estratigráfica. } \\
\text { Posible intrusión } \\
\text { estratigráfica }\end{array}$ & $\begin{array}{c}\text { Beaumont et al. 1978; } \\
\text { McBrearty y Brooks, } \\
\text { 2000; Sillen y Morris, } \\
1996\end{array}$ \\
\hline $\begin{array}{l}\text { 24. Mumbwa } \\
\text { (Zambia) }\end{array}$ & $\begin{array}{l}\text { Cueva. } \\
\text { Restos bajo un } \\
\text { túmulo de piedras }\end{array}$ & $\begin{array}{c}\text { Ocre. Estructura } \\
\text { espacial. Tecnología } \\
\text { ósea }\end{array}$ & MSA & \begin{tabular}{|c|} 
Estimación 100000. \\
Posible intrusión \\
estratigráfica
\end{tabular} & $\begin{array}{c}\text { Barham, 2000; } \\
\text { Dart y Del Grande, } \\
1931\end{array}$ \\
\hline
\end{tabular}


en hueso y más de doscientos colmillos perforados de zorro polar. Y en Sungir, desde $25 \mathrm{Ky}$, con el enterramiento de un anciano ricamente adornado o el de dos niños inhumados con sus cabezas afrontadas; además de otros enterramientos completos o parciales, como un cráneo femenino. Los ajuares depositados en estas tumbas no son comparables por su abundancia, variedad y riqueza con lo conocido hasta este momento y revelan rituales muy complejos y de gran importancia para el grupo (Abramova 1995; Kozlowsky 1992). Hacia occidente encontramos los enterramientos infantiles de Krems-Wachtberg, datados hacia $27 \mathrm{Ky}$, con cuentas de marfil incrustadas en ocre rojo, lo que indica que estos niños (dos neonatos y un bebé de tres años) eran considerados ya miembros del grupo (Einwögerer et al. 2006). También el conjunto del norte de Italia, en las cuevas de Grimaldi, muestran enterramientos con ajuares que incluyen piezas muy elaboradas (Cuevas de Cavillon y des Enfants), que deben atribuirse a Gravetiense (Mussi et al. 1989), y probablemente los enterramientos de la Barma Grande sean más recientes, hacia 20.000 BP (Bisson et al. 1996). Una cronología parecida, o incluso menor, puede tener el rico enterramiento de Arene Candide (Liguria). Más antiguos son los enterramientos de un adolescente y una joven, con objetos de adorno y ajuar así como ocre, que deben ponerse en relación con el nivel 22 de Paglicci (Puilles), Gravetiense, datado entre 28/26500 BP. (Palma di Cesnola 2001). En Gran Bretaña se encuentra el yacimiento de Paviland, en un abrigo rocoso en la costa de Gower (Gales del Sur), datado en el 26.350 \pm 550 BP (0xA-1815). La cueva contiene el esqueleto parcial de un hombre joven fuertemente teñido de ocre rojo, junto con varios adornos (Jacobi y Higham 2008). En Francia (Dordoña) pueden citarse enterramientos en Combe Capelle, donde se encontró un adulto masculino con una datación del Gravetiense de $27.680 \pm 270$ BP (Henry-Gambier y White 2003) y en el Abri Pataud, donde seis individuos (un hombre, dos mujeres jóvenes, un niño y un neonato asociado con una de las mujeres) fueron enterrados al final de la secuencia Gravetiense, hacia 21 Ky (Bricker y Mellars 1987). Estos enterramientos no están tan bien definidos como los citados para Europa oriental, pero aparecen en un contexto rico en plaquetas grabadas y arte mueble, incluyendo una figura femenina (Bricker 1995). El Abri Pataud es un yacimiento clave en el conocimiento del Paleolítico superior inicial en Europa occidental y su evolución desde un temprano Auriñaciense (35.000 BP), como veremos. Finalmente, en la Península Ibérica, aunque se citan algunos restos humanos que pudieron haber tenido un tratamiento funerario en el Gravetiense de Malladetes (Valencia) o Reclau Viver (Girona), solo la localidad portuguesa de Lagar Velho ha proporcionado un verdadero enterramiento (Zilhâo y Trinkaus 2002). El Ilamado "niño de Lapedo", en un contexto Gravetiense final, hacia 25.000 BP, aparece vinculado a los comportamientos funerarios complejos que hemos visto, aunque con un ajuar mucho más modesto, pero que incluye adornos, ofrendas de objetos y animales, hogares y ocre.

Esta descripción de los comportamientos funerarios gravetienses intenta mostrar el salto cualitativo generalizado que se ha producido en el continente europeo en los componentes simbólicos, la emergencia cognitiva en el sentido que ha sido descrita, que aparece en el este de Europa hacia 30.000 BP y parece avanzar hacia el norte (Rusia) y el oeste, alcanzando el extremo occidental, en Portugal, 5.000 años más tarde. Los datos cronológicos y genéticos sobre el origen del núcleo original asiático para el Gravetiense y su expansión hacia el este (Asia y América) y hacia el oeste europeo, se superponen cómodamente con los datos arqueológicos que venimos manejando (Semino et al. 2000; Wells 2002). Si estos grupos de humanos anatómicamente modernos, ahora bien conocidos en sus rasgos físicos y cada vez mejor en los genéticos, tuvieron contacto con los grupos neandertales residuales que se "refugiaron" el sur de Europa, y parece ser que también en el norte hasta el círculo ártico (Slimak et al. 2011), éste contacto debió de ser muy escaso y ocasional. No parece cultural y genéticamente relevante para ninguno de los dos grupos, los HN o Ios HAM. No podemos afirmar lo mismo del periodo auriñaciense anterior, entre 40/30 Ky, pero tampoco lo contrario; no hay datos en el registro arqueológico. Desde el punto de vista funerario carecemos prácticamente de información en ambos campos, el musteriense y el auriñaciense, así como en las Ilamadas culturas transicionales. Esta ausencia de datos puede deberse a imponderables de la investigación o a la generalización de prácticas funerarias que no dejan huellas reconocibles. En cualquier caso, las inhumaciones, como hemos visto, se retoman con el Gravetiense, cargadas de contenidos simbólicos espirituales, según un modelo protocolizado en las formas concretas y en el ceremonial, que muestra un rito bien definido y aceptado socialmente como exponente de un comportamiento aparentemente religioso y generalizado que obliga e incluye a vivos y muertos. Es, por tanto, un proceso de simbolización colectiva, característico del más alto nivel de simbolismo moderno elaborado en el Paleolítico europeo.

\subsection{El arte mobiliar}

Los objetos mobiliares pueden permitir dataciones más fiables que el arte rupestre, ciertamente, pero el problema de las calibraciones y las contaminaciones obliga a mantener también aquí cierta prudencia sobre la pretensión de ajustar las fechas con gran detalle, sobre todo en el rango temporal que ocupa este trabajo. Nosotros manejaremos horquillas cronológicas y grandes cifras, suficientemente representativas para ilustrar lo que pretendemos. Así, desde al menos el $35 \mathrm{Ky}$ (hay dataciones aisladas más antiguas que llegan hasta 40 Ky en Hohle Fels (Conard 2009) vemos que se con- 
figura en torno al alto Danubio, en el Jura Suabo de la Alemania meridional, un conjunto de yacimientos ya clásicos en el análisis de los orígenes del arte mueble paleolítico. La revisión de trabajos antiguos y la puesta en marcha de nuevos proyectos en la última década han proporcionado nuevas y espectaculares piezas e informaciones muy pertinentes para el tema de este trabajo. Haremos una rápida revisión de lo más característico.

En la Cueva de Hohle Fels el Auriñaciense se sobrepone a cinco niveles musterienses tardios en los que aparecen algunos impactos y marcas de corte en hueso. No se han hallado adornos u otras huellas de simbolismo. Sin embargo el Auriñaciense ha entregado una colección de pequeñas esculturas en marfil pertenecientes al nivel basal, datado al menos en 35 Ky (Conard 2009; Conard et al. 2003). Vamos a centrarnos en tres piezas: Una figura femenina de tipo Venus, un híbrido hombre-felino de tipo teriántropo, ambas en marfil, y una flauta de hueso (Lám. 1). La escultura de tipo Venus, prefigura torpemente la tipología posterior de este tipo de representaciones gravetienses y exagera casi con obscenidad sus rasgos sexuales. Su inequívoca vocación expresiva y su cronología la ponen en el inicio de estas representaciones de carácter sexual, que han recibido interpretaciones diversas pero que muestran a las claras un alto contenido simbólico. La figura del hombre-felino, de pequeño tamaño, indica la existencia de este tema, que relacionaremos con los llamados mediadores paleolíticos 0 teriántropos, en el Auriñaciense antiguo de esta área. Finalmente, una flauta magníficamente conservada, muestra la existencia de actividades musicales en un momento tan temprano. También es pertinente señalar la existencia de restos de pintura en bloques desprendidos de la pared y contenidos en niveles gravetienses (Hahn 1992).

También en la cueva de Geissenklösterle aparece el Auriñaciense antiguo en, al menos, $37 \mathrm{Ky}$ (Richter et al. 2000). El arte mueble que nos interesa se data hacia $33 \mathrm{Ky}(37 \mathrm{Ky}$ por $\mathrm{TL}$ ) en el nivel Ilb, y consiste en un bajorrelieve con la representación muy deteriorada de una figura humana, conocida como "el orante". El rectángulo de marfil sobre el que se talló la pieza muestra en su parte posterior un conjunto de marcas (48), realizadas con discontinuidad temporal, interpretadas como un posible calendario lunar (Bosinsky 2005). También merece mención una flauta similar a la de Hohle Fels hecha sobre un radio de cisne, que muestra las incisiones transversales características de estas piezas a lo largo del Paleolítico superior (Conard et al. 2009), configurando un modelo. Finalmente, en este nivel se ha hallado un fragmento de caliza con restos de pintura roja, negra y amarilla, donde se aprecia una forma geométrica triangular. Seguramente el signo más antiguo conocido hasta la fecha en Europa. También se han hallado algunos fragmentos de pared con restos de pintura e incisiones en los niveles gravetienses. Esto muestra la temprana existencia, como se ha señalado en Hohle Fels, de decoraciones parietales desaparecidas en los yacimientos del área (Hahn 1987 y 1992). Otras figuras del nivel inferior, Ila, muestran esculturas de mamut y bisonte con trazos en su cuerpo, pero sobre todo merece citarse una pequeña figura de $5 \mathrm{~cm}$. de altura, que suele interpretarse como un oso erguido y pudiera formar parte de ese tipo de piezas que hemos definido como teriántropos. Mucho más clara es la impresionante escultura del hombreleón de Hohlentein-Stadel (Hahn 1970), realizada en marfil de mamut y que mide $29 \mathrm{~cm}$. de altura. Muestra un cuerpo humano erguido con cabeza de león y siete incisiones en su brazo, aparecido en un contexto Auriñaciense, con hogares y adornos (nivel IV, datado en 31.750 \pm 1150 BP. H 3800-3025). Esta escultura se ajusta formalmente al modelo visto en la escultura antropomorfa de la vecina cueva de Hohle Fels. Finalmente, es obligado citar el conjunto de esculturas animales de Vogelherd. En esta cueva, sobre niveles musterienses se excavaron dos niveles auriñacienses antiguos (V y IV), datados entre 36/30 Ky (Conard et al. 2003) con azagayas de base hendida. Ambas ocupaciones entregaron un conjunto de esculturas de animales en marfil de una belleza extraordinaria y un naturalismo sorprendente en los comienzos del arte. El mamut transmite al observador su fortaleza, las leonas su fiereza y agilidad, y el caballo lo poderoso y elegante de sus movimientos. Una escultura cilíndrica, de diseño muy masivo, quizá inacabada aunque presenta numerosos trazos y puntos en su contorno, es generalmente interpretada como antropomorfo.

Los anteriores datos muestran cómo desde los niveles del Auriñaciense antiguo, en torno a $37 \mathrm{Ky}$, en el conjunto de yacimientos del Alto Danubio, en el suroeste de Alemania, comienza una actividad artística inexistente hasta entonces en Europa, donde hubo grupos de HAM quizá desde $45 \mathrm{Ky}$ (Hoffecker 2011; Benazzi et al. 2011) que configura unos modelos que van a perdurar, con las lógicas variaciones, a lo largo del Paleolítico superior europeo. Estos modelos se refieren a las figuras femeninas denominadas Venus, a la representación de seres híbridos animal-humano, o teriántropos y, finalmente, a la confección de un tipo de flautas sobre huesos de ave con incisiones perpendiculares al eje de la pieza. Estos objetos van acompañados de esculturas animales, con presencia significativa de aquellos que suelen definirse como peligrosos (león, mamut, oso) y, en menor medida, caballos y bisontes. También parece relevante señalar la existencia de pinturas y grabados rupestres, desgraciadamente desparecidos. El emplazamiento de este conjunto de yacimientos, en la cuenca del Danubio, que ha funcionado desde el Paleolítico inferior como la gran vía interior de comunicación horizontal en Centroeuropa, es igualmente significativo. Así se observan claros paralelos en algunas piezas de la cultura Surgir-Streleckaja, en los comienzos del Paleolítico superior de Europa oriental, aunque las dataciones, a menudo contradictorias, rebajan sus comienzos hasta 
28 Ky (Bosinsky 2005). Pero también se documentan claras influencias de estas manifestaciones simbólicas mobiliares hacia el sur donde, como veremos, aparecen áreas de poblamiento auriñaciense más intenso, coincidiendo con el aumento del frio que marca el comienzo de Würm III, hacia $35 \mathrm{Ky}$, o incluso más antiguas, en Aquitania (abrigos de Lartet, Blanchard, Cro-Magnon, Cellier...), en Italia (Fumane) y la costa cantábrica (Viña, Castillo...) (Lorblanchet 1999). En resumen, tenemos un registro arqueológico en el alto $\mathrm{Da}$ nubio que muestra actividades artísticas muy desarrolladas, probablemente acompañadas de un relato que ha dejado algunas huellas en forma de pintura en las paredes de las cuevas, y unos ritos que pueden incluir actividades musicales en su desarrollo. Así aparecen patrones de comportamiento simbólico que configuran tipos de piezas o temas decorativos que se irán extendiendo por Europa y veremos aparecer en algunos yacimientos auriñacienses más recientes y que se generalizarán en el Gravetiense. No obstante en el resto de Europa, a pesar del temprano poblamiento por HAM, no hay nada comparable al conjunto de yacimientos suabo en esa horquilla temporal (37-30 Ky) en lo que se refiere al arte mueble.

\subsection{El arte rupestre}

Las pinturas y grabados que aparecen en los abrigos exteriores o en la profundidad de la cueva, así como los bloques desprendidos de las paredes con restos de arte, constituyen la más clara prueba del comportamiento simbólico que venimos analizando. Estas manifestaciones quedan abiertas a la libertad y creatividad del artista, donde pueden plasmarse con mucha mayor autonomía y versatilidad los contenidos, simbólicos o no, que manejaban los grupos paleolíticos. Por ello ha sido tradicionalmente el gran campo de debate de la arqueología prehistórica y de la etnografía. Trataremos de analizar sintéticamente lo más significativo de los comienzos de tales manifestaciones, entre más o menos 35/25 Ky, para ponerlo en relación con los datos anteriores. El C14AMS y las dataciones de costras calcáreas por U/Th y TL han hecho tambalearse algunas convicciones aparentemente bien establecidas. Debemos ser prudentes con la fiabilidad de los datos, pues hay frecuentes problemas de contaminación, pero el conjunto de dataciones muestra inequívocamente un comienzo temprano y sorprendentemente complejo en varias áreas europeas (Lorblanchet 1999; Fortea et al. 2004). Dos hipótesis clásicas, la de la evolución estilística del arte parietal y la del avance desde el exterior al interior de la cueva, deben ser muy matizadas, aunque no arrumbadas definitivamente como han propuesto los Ilamados post-estilistas; y en cierta medida se puede recuperar la idea del ciclo breuliano auriñaco/perigordiense como entidad específica de contenidos. Veámoslo brevemente.
En la zona cantábrica Fortea (1994) ha descrito lo que él llama el "horizonte anicónico" de las manifestaciones rupestres, bien datadas arqueológicamente en la Viña en relación con el Auriñaciense antiguo, hacia 36.5 Ky (Fortea 1992), y en al menos $29 \mathrm{Ky}$ para la cueva del Conde (Fernández et al. 2005). Son profundas incisiones realizadas en el exterior, junto al área de habitación, que pudieron estar coloreadas y probablemente testimoniaban la propiedad o derecho de uso del sitio, significado que en otras áreas se ha atribuido a las representaciones de manos. Una docena de yacimientos cantábricos con ocupaciones tempranas exhiben tales grabados anicónicos, cuya realización se amplia al Gravetiense (Rasilla et al. 2010) y se extiende hasta Italia, tanto en yacimientos auriñacienses (Cavillon) como del Paleolítico superior avanzado (Leonardi 1988). En el caso cantábrico, a este horizonte descrito le sigue otro "icónico", igualmente exterior, formado por caballos, uros y, sobre todo, ciervas trilineales, en un diseño simple, muy característico y de gran belleza (Viña, Lluera, Torneiros, Chufín, Hornos de la Peña, Venta la Perra...). Queremos destacar la ausencia de animales considerados esencialmente como peligrosos, tales como felinos o mamuts, tan frecuentes en el imaginario mobiliar europeo de esta época. Estos grabados exteriores cantábricos son indudablemente gravetienses y se prolongan hasta el Solutrense (Fortea 1990). También parece que es en el Gravetiense cuando el arte comienza a invadir la profundidad de las cuevas cantábricas, aunque se mantenga actividad artística exterior. Hay cierto consenso entre los especialistas en dudar de la atribución auriñaciense para ciertas figuras y signos cantábricos aunque lo sugieran fechas como las manchas negras de Candamo, asociadas a la representación de toros del muro de los grabados, consideradas las figuras más antiguas de la cueva asturiana, que llegan hasta $33 \mathrm{Ky}$ (Fortea 2007). De fecha similar pueden ser los antropomorfos pintados en rojo en Tito Bustillo y quizá una mano del mismo Conjunto $V$ cuyo contexto arqueológico ha dado una fecha de $32.990 \pm 450 B P$ (Balbín et al. 2007); o algunas pinturas del mismo color en el interior de cuevas del desfiladero del río Carranza, al este de Cantabria. Alli se dataron por TL costras estalagmíticas en $35 \mathrm{Ky}$ que recubrian pinturas rojas en la cueva de Pondra. Quizá algo similar ocurra en la cueva vecina de Arco B (González Sainz y San Miguel 2001). En cualquier caso estas pinturas interiores son excepcionales en el Auriñaciense cantábrico, donde yacimientos con importantes ocupaciones de ese periodo, que incluyen arte mueble en sus ocupaciones exteriores y largas secuencias artísticas en su interior, como la Cueva del Castillo, no tienen una representación parietal significativa en el periodo auriñaciense.

Nuevas dataciones (U-Series), dadas a conocer en el momento de entregar este texto, realizadas sobre espeleotemas y costras calcáreas confirman la antigüedad de las pinturas auriñacienses que recubren y que nos interesan especial- 
mente en este trabajo. Sobre todo las referidas a manos, signos y teriomorfos aunque aún es pronto para apreciar si son limitadas o más generalizadas de lo que se creía. En la cueva de Tito Bustillo se ha datado un teriomorfo de pigmento rojo, que ya hemos citado, en una horquilla temporal que oscila entre los 35.500 y 29.600 BP. En la cueva de Altamira un signo abstracto se dató en 35.600 BP. La cueva de El CastiIlo ofreció fechas para un disco rojo entre 36.000 y 34.100 BP., una mano en negativo de, al menos, 37.300 años y otro disco rojo datado en más de 40.800 BP (Pike et al. 2012). Estos datos confirman la existencia en el Auriñaciense de las manifestaciones gráficas, así como del aislamiento social de algunas de ellas dentro de la cueva con connotaciones simbólicas aparentemente diferentes de las que se sitúan en las áreas de hábitat.

Será en el Gravetiense, desde aproximadamente $28 \mathrm{Ky}$, cuando el arte penetre de forma generalizada en la profundidad oscura y numinosa de las cuevas cantábricas. En cualquier caso, no hay un límite nítido entre Auriñaciense y Gravetiense, sino una continuidad difícil de datar directamente con métodos físico-químicos por tratarse frecuentemente de pinturas rojas con escaso o nulo contenido orgánico.

Del arte rupestre que durante el Gravetiense se realiza en el interior de las cuevas del norte de la Península lbérica nos interesan, fundamentalmente, tres temas representados ya vistos anteriormente: signos de contenido sexual explícito, representaciones de manos y figuras antropomorfas. Entre los primeros destaca la representación de vulvas grabadas y pintadas, atribuidas alternativamente a Auriñaciense y/o Gravetiense. Aunque existen algunas estalactitas coloreadas de rojo con connotaciones fálicas (Cueva de la Lloseta) o representaciones humanas ictifálicas, el sexo masculino no mereció una atención especial en las manifestaciones rupestres o mobiliares de los inicios del Paleolítico superior. Sin embargo, el sexo femenino, a pesar de su más difícil representación, constituyó un tema repetido en numerosos yacimientos y santuarios. Son frecuentes en el cantábrico las coloraciones en rojo de grietas ovaladas que se abren en las paredes de las cuevas y semejan vulvas femeninas (Tito Bustillo, Buxu, Mazaculos, etc.), la representación de signos triangulares o acampanados o la explícita representación del sexo femenino, incluso en santuarios interiores monotemáticos, como en el camarín de Tito Bustillo, donde podrían tener cronología auriñaciense. Estos signos siempre aparecen pintados en rojo, aunque también deben citarse algunos signos vulvares grabados en el exterior en contextos gravetienses (Lluera, Micolón). Por tanto, en ausencia de esculturas femeninas o venus comparables a las centroeuropeas, en los comienzos de las representaciones artísticas, existen en el área cantábrica representaciones de marcado contenido sexual, igualmente femeninas. Las escasas representaciones humanas que aparecen en el interior de las cue- vas son también femeninas y están pintadas en rojo. Se han atribuido al Auriñaciense -Tito Bustillo- (Balbín et al. 2007) y al Gravetiense -Llonín- (Fortea et al. 2004). Las máscaras humanas identificadas en el interior de algunas cuevas (Castillo, Altamira, Candamo, etc.) suelen estar pintadas en negro, aprovechando relieves naturales antropomorfos y se les asignan cronologías más recientes. Finalmente, la representación de manos, generalmente pintadas en negativo y color rojo, suelen atribuirse al Gravetiense (González Sáinz 1999) y se distribuyen por todo el recorrido de la cueva: en el exterior (Fuente del Salín), en los corredores intermedios (Castillo, Cudón, Tito Bustillo) o en espacios interiores profundos (Galería inferior de la Garma) aunque a juzgar por el contexto en el que algunas aparecen pudieron ser realizadas también durante el Auriñaciense (Tito Bustillo).

Como hemos visto, en el ámbito cantábrico existe un conjunto de yacimientos con manifestaciones anicónicas e icónicas, primeramente al exterior y poco más tarde, quizá dentro del mismo Auriñaciense, al interior de las cuevas, que muestran un arte rupestre bien definido en un número reducido y repetitivo de temas. Todo ello en un área bien delimitada geográficamente, a lo largo de un estrecho pasillo entre la cordillera cantábrica y la costa. Algo similar puede apreciarse en Francia, en la Dordoña en general, y singularmente en el Valle de la Vezére. Esta región constituye uno de los ámbitos con mayor concentración de santuarios rupestres, algunos emblemáticos en la historiografía paleolítica. Aunque no ha aparecido un horizonte anicónico tan antiguo como el del cantábrico occidental, muestra algunos temas similares a los ya vistos. Así, varios yacimientos han proporcionado bloques desprendidos de las paredes de la cueva con representaciones vulvares grabadas, como en La Ferrassie, acompañadas de toscas figuras animales grabadas, desde el Auriñaciense I. En la capa siguiente, Auriñaciense II, aparecen fragmentos de la bóveda del techo con restos de pintura. Similares vulvas grabadas y restos de pintura y grabados aparecen en las paredes y/o niveles auriñacienses de La Croze a Gontran, Abri Balchard, Abri Cellier y Abri Castanet (Delluc y Delluc 1991). En este último, donde se han hallado hasta 12 bloques con vulvas grabadas, el nivel auriñaciense de base se ha datado entorno a $35 \mathrm{Ky}$ (Vialou 2004). Aunque existen otros yacimientos con representaciones sexuales femeninas, los citados muestran lo estandarizado de este tema en la zona durante el Auriñaciense. En el periodo Gravetiense y siguientes aparecen las esculturas femeninas o Venus, como en otros sitios de Europa central y oriental, así como las representaciones rupestres de cuerpos de mujer con referencia explícita al sexo, grabadas y esculpidas en bajorrelieve. Esto muestra el profundo arraigo de un concepto que aparece desde los inicios de las representaciones gráficas simbólicas. No hay manos pintadas o representaciones de teriántropos de indudable cronología Auriñaciense en esta región. Por el contrario, son muy frecuentes en el Gravetiense las manos 
positivas y negativas no solamente en la Dordoña, sino en otros muchos yacimientos, singularmente en la zona de L'Ariege donde yacimientos como Gargas muestran más de doscientas manos negativas, mayoritariamente en negro, en agrupamientos interiores pero no muy alejados de la entrada de la Galería Inferior. Algunas esquirlas óseas extraídas de la pared han dado una fecha en torno a $26.5 \mathrm{Ky}$, lo que refuerza su atribución Gravetiense (Clottes et al. 1992).

En 1994 se descubrió en la región de L'Ardèche, en el sureste de Francia, la cueva de Chauvet (Chauvet et al. 1995; Clottes 2001). Su arte rupestre resultó extraordinariamente sorprendente en cuanto a las técnicas utilizadas, los temas tratados, la disposición de las figuras y, sobre todo la cronología asignada, entre 32/30 Ky (Clottes et al. 1995), que se corresponde con una fase terminal del auriñaciense. En lo que a nosotros nos interesa resaltaremos que los animales peligrosos representados, inusualmente numerosos, se corresponden con los que hemos visto en los yacimientos suabos del alto Danubio, tanto en las especies representadas como en las convenciones utilizadas para su caracterización. También merece destacarse en la cueva de Chauvet la presencia de manos negativas, de órganos sexuales femeninos y una figura pintada en negro, con cabeza de bisonte y piernas humanas, que puede ser incluida entre los teriántropos o mediadores paleolíticos que hemos descrito. Estas figuras híbridas humano-animal también están presentes en algunos santuarios de la Dordoña que hemos visto (Gabillou), en L'Ariége (Trois Frères) o en el cantábrico (Castillo), aunque generalmente se les asignan cronologías más recientes. Auriñaciense también sería la figura humana con cornamenta animal, que sostiene un objeto en la mano derecha, pintada en negro en un bloque aparecido junto a otros bloques con restos de pintura, desprendidos de las paredes de la cueva de Fumane, en el Veneto italiano, en niveles datados entre 36 y 32 Ky (Broglio y Dalmeri 2005). Pero la gran aportación de Chauvet al tema que tratamos es que a todos esos elementos que hemos venido constatando como componentes arqueológicos tempranos del más alto grado del simbolismo moderno elaborado, que son las conductas religiosas estructuradas, añade un relato largo y explícito, muy cuidado técnicamente -con mucho "oficio"-, complejo en su conceptualización y que debió de resultar evidente en su representación.

\section{CONDUCTAS SIMBÓLICAS PALEOLÍTICAS: UNA INTERPRETACIÓN DE LOS DATOS}

Hemos visto cómo las conductas simbólicas son el resultado del desarrollo evolutivo, cognitivo y cultural de sus autores; y que los avances hacia una mayor simbolización dentro de cada especie humana se producen solamente cuando hay condiciones socioculturales y medioambientales suficientes. Por tanto, su explicación es biológica y cultural, con carácter progresivo y acumulativo. $Y$ que su demostración es arqueológica, pues solamente puede ser evidenciada a través de los comportamientos humanos que aparecen en el registro paleolítico. También es importante señalar la importancia del análisis regional de los restos pues muestran la geografía real, de carácter anual, de los grupos paleolíticos, lo que no aparece en la escala local ni en la continental. Todo ello considerado desde lo que hemos definido como estructuralismo funcional. Siguiendo los niveles de simbolismo anteriormente señalados (2.3.) tenemos:

\subsection{Simbolismo arcaico}

Constituye el primer estadio de nuestro esquema, en el que no existen evidencias de simbolización (Cuadro 4). No obstante, la conservación diferencial de los restos arqueológicos dificulta las afirmaciones categóricas, otorgando siempre el beneficio de la duda. En función de los datos arqueológicos (tecnológicos y socioeconómicos) se puede relacionar con un lenguaje fonológico y gesticular difícil de valorar, alcanzando de forma irregular en el tiempo y en el espacio criterios básicamente descriptivos con ciertos inicios de desplazamiento cognitivo. Su acción se limitaría a una transmisión de contenidos simples e inmediatos, fundamentalmente vinculados a la colaboración y a la supervivencia. Dentro de este nivel de simbolización arcaica estarian los grupos humanos preachelenses y achelenses, hasta $400 \mathrm{Ky}$ en Europa, donde hay indicios de nuevos comportamientos más complejos.

\subsection{Simbolismo primitivo}

La aparición en la Sima de los Huesos, Atapuerca, de más de una treintena de individuos en las condiciones descritas, además de un cierto gusto por la belleza evidenciado en la selección de las materias líticas para fabricar herramientas, buscando la simetría en los bifaces y la estandarización tipológica, muestra una nueva y desconocida actitud entre los heidelbergensis de cultura achelense, hacia $400 \mathrm{Ky}$ Los enterramientos ya resultan indudablemente intencionados entre los neandertales de Europa y de estos y de los HAM en el Próximo Oriente, desde al menos 70 Ky para los primeros y de $100 \mathrm{Ky}$ para los segundos, todos ellos con cultura musteriense o asimilable. Estos comportamientos funerarios son intencionales pero con una pobre estandarización y una distribución geográfica muy local. El tipo de ceremonias y los escasos materiales que acompañan a los muertos no evidencian que tales prácticas funerarias incluyan un componente simplemente espiritual y mucho menos religioso, aunque muy probablemente si se acompañan de un sentimiento emocional $y_{\text {, }} \sin d u d a$, representan un gesto de individualización social. Esta consideración, más algu- 
nas marcas sobre hueso y otras prácticas sociales vinculadas con el desarrollo de los conceptos de individualización (principalmente social y en menor medida personal) y de las conductas relacionadas con los conceptos espaciales y temporales (desplazamiento cognitivo), marcan un nivel superior de simbolización que, sin duda, necesitó la existencia de un lenguaje descriptivo con ciertos componentes sintácticos más complejos que en el nivel anterior. Su fin, por medio de cierta articulación sonora ascendente en complejidad y un importante componente gesticular, sería la realización de tales conductas. Estos datos nos inducen a incluir estos grupos en un nivel de simbolismo primitivo.

\subsection{Simbolismo moderno}

El nivel de simbolismo moderno se diferencia del anterior por el alto desarrollo de valores individuales y sociales; por un manejo de las coordenadas temporales y espaciales más complejo y matizado que en los niveles anteriores $y$, sobre todo, por el uso consciente e intencionado de símbolos que representan estos avances cognitivos. Es cuando se alcanzan los niveles de autoconciencia necesarios para que se inicie la individualidad personal, dentro de una individualidad social posiblemente más desarrollada, imprescindible para la creación de toda conducta simbólica compleja (Alvargonzález 2005; Bueno 1996). Con este desarrollo cognitivo se logra una emergencia conductual fundamental para el comportamiento humano. La conciencia hizo posible las siguientes funciones: el lenguaje moderno, la memoria extensa, el razonamiento, la creatividad, y el edificio de la cultura. En conjunto ha mejorado la adaptabilidad y ha permitido crear nuevas soluciones para los problemas de la vida y la supervivencia en muchos entornos (Damasio 2010). Es decir, dotó a los seres humanos una gran reflexividad de su pensamiento y conducta, que se traduce en una gran capacidad para la producción de rápidos cambios conductuales encaminados a solucionar problemas adaptativos y sociales (flexibilidad conductual) (Edelman y Tononi 2000; Mora 2002).

Para que esto sea posible debe existir un nivel de lenguaje que permita la argumentación y el manejo del tiempo y el espacio en todas sus variantes. $Y$ para explicarlo y hacerlo evidente se recurre al símbolo que trasciende la materialidad inmediata, lo que posibilita los comportamientos espirituales, necesitados del uso de metáforas en el lenguaje. Ese nuevo universo que se abre debe ser gestionado y explicado, lo que hace necesario una forma de relato del mismo. La coherencia del relato y la eficiencia, en términos adaptativos, del manejo de esa dimensión espiritual produce la aceptación social del mismo, protocolizándose estas prácticas para una mayor efectividad. Hasta el punto en que la sociedad asume colectivamente los principios narrados y los valores que comporta, dando lugar al nacimiento de las con- ductas espirituales, religiosas y a las religiones propiamente dichas. Este es un largo proceso, con numerosos estadios intermedios, que se solapan sincrónicamente según ámbitos regionales. La mayor riqueza de restos arqueológicos y la posibilidad de ordenarlos cronológicamente con mayor fiabilidad nos permite formular hipótesis más matizadas sobre su desarrollo.

\subsubsection{Simbolismo moderno básico}

Lo que caracteriza a esta etapa del desarrollo de la simbolización es la clara manifestación de la individualidad social y la personal muy entroncada en la anterior. La individualización personal que pone de manifiesto el adorno corporal mediante pinturas y objetos, muestra la diversidad social y abre el camino a la jerarquización, las diferencias y las desigualdades en el grupo. Mientras que la simbolización social lo cohesiona mediante referentes comunes y muy probablemente lo vincula a un territorio. Esta etapa pudo haberse desarrollado en Europa, en sentido estricto, entre 50 y $40 \mathrm{Ky}$ afectando a los HN de cultura musteriense y transicionales (Chatelperroniense y Ulluziense) y a los primeros HAM llegados al continente desde $45 \mathrm{Ky} \mathrm{El} \mathrm{simbo-}$ lismo moderno básico se mantiene en ámbitos regionales, más o menos aislados, de grupos humanos neandertales y modernos hasta $30 \mathrm{Ky}$, incluso fechas más bajas, originando una situación de mosaico en cuanto a desarrollo cognitivo en el panorama europeo.

En esta etapa cambia o desaparece la conducta funeraria de inhumación, pues casi no hay enterramientos o son muy dudosos, como hemos visto. El uso de materias orgánicas como hueso y asta, con formas estandarizadas, abre paso a una nueva tecnología que culminará en las obras de arte mobiliar. En algunas zonas se marca el territorio o el hábitat del grupo mediante profundas incisiones en la roca, marcas imperecederas que muestran la existencia de una territorialidad exclusiva o compartida que permite suponer la existencia de otras formas perecederas de expresión que han desaparecido.

Esta dinámica entre lo personal y lo social, entre lo social y lo territorial debe ser argumentada con un lenguaje suficientemente rico para ello. Pero no han quedado huellas del relato social que debe acompañar a las conductas espirituales en este nivel del simbolismo.

\subsubsection{Simbolismo moderno elaborado}

Durante el desarrollo de la etapa anterior, sincrónicamente y en ámbitos regionales restringidos, se produce un desarrollo cognitivo que dará lugar a un salto cualitativo en el proceso de simbolización humana. El registro arqueológico muestra un conjunto de yacimientos en el suroeste de la actual Alemania, un grupo regional bien delimitado en el Jura suabo, donde existen las pruebas materiales del relato social que debe acompañar la explicación de conductas es- 
pirituales y protorreligiosas. En el Auriñaciense antiguo de Hohle Fells, entre 40 y $35 \mathrm{Ky}$, encontramos todos los elementos arqueológicos que van a generalizar posteriormente un modo de acceso y gestión del mundo espiritual. Aparece la primera escultura femenina, torpe y casi obscena en su caracterización sexual, pero que ya marca un modelo de gran arraigo y difusión posterior. Aparece también una escultura de teriántropo, como la anterior en marfil, que igualmente se verá repetida en otros yacimientos y sugiere la posible existencia de mediadores numínicos con el mundo animal en el sentido que hemos descrito. Las plaquetas pintadas desprendidas del techo y contenidas en niveles gravetienses muestran también que se ha iniciado el relato social en este proceso de simbolización, tal vez acompañado de música a juzgar por la existencia de instrumentos musicales. Esto se repite en otros yacimientos de la región igualmente definidos como Auriñaciense antiguo (Vogelherd, Geissenklösterle, Hohlentein-Stadel) y datados antes de $35 \mathrm{Ky}$, acompañado de un conjunto de figuras animales, con representación abundante de los llamados peligrosos, de una belleza sobrecogedora. La repetición de los modelos en diversos yacimientos del área muestra la generalización social de esta simbolización, asociando por primera vez todos los marcadores de lo que hemos considerado una conducta religiosa naturalista, o protoreligiosa, probablemente muy poco estructurada, pero impregnada de manifestaciones espirituales con gran capacidad de influencia social, aunque todavía no pueda hablarse de una verdadera religión.

De una forma independiente, a partir de un idéntico sustrato de códigos comunes asimilables al simbolismo moderno básico, y/o quizá estimulado por los contactos con los grupos auriñacienses suabos en un ambiente sociocultural adecuado, vemos aparecer poco más tarde algunos de los marcadores de este simbolismo moderno elaborado hacia el sur aunque puede observarse cierta personalidad o rasgos individualizadores en cada área dentro del sustrato común. En el centro y sur de Francia, pero singularmente en la Dordoña, se multiplican los adornos personales en los niveles auriñacienses, que también contienen representaciones de vulvas y animales en fragmentos de roca desprendidos de las paredes del abrigo o de la antecueva, donde también se habita cotidianamente, aunque aún no aparecen representaciones de teriomorfos, que sí se documentan en el Auriñaciense del Véneto italiano por encima de $32 \mathrm{Ky}$ Por esas fechas debe situarse el arte rupestre de Cueva Chauvet, en el sur de Francia. Algunos animales peligrosos del sorprendente conjunto recuerdan vivamente a las esculturas alemanas en marfil y la presencia de un teriántropo, en este caso animalizado en mamut, muestran nuevamente el avance de los marcadores simbólicos que ahora realizan su relato también en el arte rupestre con una escenografía de una belleza sobrecogedora y muestran esa aludida personalidad regional. En la península Ibérica no hay nada similar a lo que acabamos de citar. Solamente algunas pinturas rojas de discutida atribución Auriñaciense distribuidas entre Cantabria y Asturias. Lo más significativo, las vulvas circulares y los antropomorfos de Tito Bustillo, en un contexto de probable cronología Auriñaciense, sobre todo si tenemos en cuenta las recientes dataciones, que enlazan con los temas descritos.

Hacia 28 Ky se produce en Europa un cambio cultural de rápida expansión que definimos como Gravetiense, quizá estimulado por la llegada de poblaciones en sentido este-oeste cuya intensidad puede explicar el diferente grado de "gravetización" según qué aspectos en el mismo sentido geográfico. Sin embargo, el nuevo modelo crea redes sociales que posibilitan intercambios más rápidos, permanentes y entre grupos muy distantes, y su eficiencia lo consolida en poco tiempo. En este nuevo nicho cultural y cognitivo los marcadores de simbolización experimentan un cambio en cantidad y calidad, y el relato que los acompaña muestra el salto cualitativo, socialmente generalizado, a conductas religiosas propiamente dichas. Se recupera en el registro arqueológico la conducta funeraria de inhumación, que en el este de Europa adquiere rituales extraordinariamente complejos y ricos que van extendiéndose hacia occidente, perdiendo progresivamente su originario esplendor, pero manteniendo la esencia del rito, hasta documentarse en el extremo atlántico europeo, en Lagar Velho (Portugal), cinco milenios más tarde.

La dirección que siguen las esculturas femeninas -venus- parece la contraria. Se generalizan desde Francia hasta Siberia, en esa dirección. La persistencia del modelo, aún con las variantes locales y cronológicas, que trasciende al propio paleolítico, muestra lo arraigado de un concepto básico en el desarrollo de la emergencia de las conductas simbólicas y el origen de los comportamientos religiosos, aún cuando estas esculturas se hayan interpretado tan diversamente. Incluso algunas de estas figuras han aparecido en contextos altamente ritualizados. No han aparecido, sin embargo, hasta el presente, esculturas de Venus gravetienses en la Península lbérica. Por el contrario son frecuentes las representaciones de vulvas, a veces muy explícitas, tanto en grabados exteriores, al estilo triangular francés, como las de formas circulares pintadas en rojo. Estas últimas conquistan la profundidad de la cueva, como hemos visto, igual que las representaciones de teriántropos, las figuras femeninas y las manos, más frecuentemente negativas. También en el cantábrico son especialmente remarcables los santuarios exteriores con animales grabados a surco profundo, estando ausentes los más temibles y con representación frecuente de ciervas, que tendrán algún significado especial en esta área hasta el magdaleniense medio. Por tanto, también aparece una forma específica de relato en el Gravetiense cantábrico.

Esta rápida descripción muestra, a nuestro juicio, la emergencia cognitiva que se ha producido en el nivel de simbolización que hemos definido como moderno elaborado. La difícil precisión de las fases internas y el carácter 
regional de los avances le confiere aspecto de mosaico, lo que dificulta la visibilidad de las hipótesis. Pero resulta evidente que durante el Gravetiense culmina y se generaliza un comportamiento simbólico bien protocolizado en rituales complejos y bien definidos, repetidos durante generaciones y con un consenso social generalizado. Es decir, constatamos la existencia de un comportamiento religioso como práctica de una religión primaria, en el sentido en que la hemos descrito, que pudo aparecer regionalmente durante el Auriñaciense pero que solo en el Gravetiense adquiere el grado de interiorización necesario para obligar de forma generalizada a un modo de vida. Esto se sugiere, al menos, al tratar los temas capitales de la vida y la muerte (el sexo y los enterramientos), los temores y angustias (animales peligrosos), el acceso y manejo del mundo sobrenatural (los mediadores o teriántropos) y el relato explícito que hace visible y aceptable socialmente esta nueva visión del mundo. La eficiencia de este modelo y su adaptabilidad le han asegurado su larga pervivencia.

\section{CONCLUSIONES}

La gran mayoría de los autores que han trabajado en los problemas cognitivos del Paleolítico han llegado a conclusiones generales de parecido fundamento aunque con diferente forma de producción (Merlin Donald 1991; Noble y Davidson 1996; Steven Mithen 1998; Malafouris 2008; Renfrew 2008; Coolidge y Wynn 2011). Todos admiten la necesidad de estudios ampliamente interdisciplinarios para su realización. También confluyen en la importancia que tiene el medioambiente y el lenguaje en la estructuración ontogénica del cerebro de todo recién nacido y del aprendizaje de todas las formas culturales. Sin embargo, el principal problema que siempre se les ha achacado, sobre todo al Procesualismo, es la dificultad o subjetiva aplicación de sus teorías generales al registro arqueológico, que aparece como un objetivo a superar. El propio Renfrew (2008) no encuentra una explicación convincente a la revolución simbólica moderna, arqueológicamente evidenciada desde hace 60.000 años, cuando nuestra especie llevaba muchos milenios de existencia y es poco probable la producción de cambios genéticos como responsables de tal cambio, en lo que denomina sapient paradox. En su opinión, tal dificultad arqueológica sólo puede encauzarse desde un punto de vista neurocientífico que explique las propias características psicobiológicas de nuestro cerebro y las formas de interacción con el medioambiente con el que interactúa. El desarrollo de un modelo psicobiológico, dentro de una teoría general interpretativa, el estructuralismo funcional, nos ha permitido abordar este problema y formular una hipótesis explicativa.

La capacidad de simbolización de los seres humanos es un proceso evolutivo de naturaleza biológica y cultural que pasa por diferentes fases en su construcción hasta culminar en el Paleolítico superior inicial con los comportamientos religiosos. Este proceso es observable en el registro arqueológico europeo, con un lento desarrollo del mismo desde el Paleolítico inferior. Aunque es constatable un progresivo aumento en su complejidad paralelamente a la evolución biológica y cultural de los grupos humanos europeos, no existe una relación causal entre especie biológica o cultura específica con un determinado nivel de simbolismo. El fenómeno es más complejo y, para desarrollarse, necesita que existan las condiciones biológicas y culturales suficientes, pero también que se cree el entorno necesario y adecuado para que emerja y se consolide. $Y$ esto no se produce a escala continental, sino regional. Por tanto, pueden convivir diferentes niveles de la escala de simbolización en una misma especie biológica o en un mismo periodo cultural, como así ha sido. La capacidad de simbolización es una variable más a observar en el registro arqueológico del paleolítico, con sus marcadores específicos, que muestran primeramente desarrollos regionales y una posterior asimilación a escalas más amplias al demostrar su eficiencia adaptativa. Este desarrollo en mosaico dificulta enormemente su comprensión. Ésta solo será posible determinando claramente sus huellas arqueológicas y ordenándolas en el tiempo, en una confluencia de los avances evolutivos y su difusión. Este complejo proceso, cuyo análisis afecta al desarrollo de diversas ciencias, nos ha permitido formular las hipótesis anteriores, proponiendo un desarrollo secuencial desde las formas arcaicas hasta las modernas elaboradas, caracterizando cada fase según los datos actualmente disponibles. • 


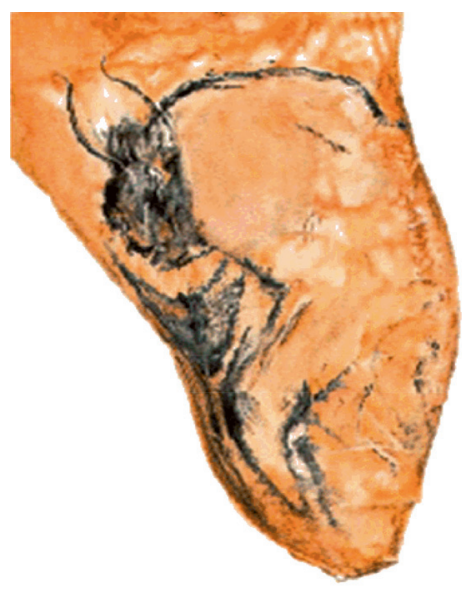

1

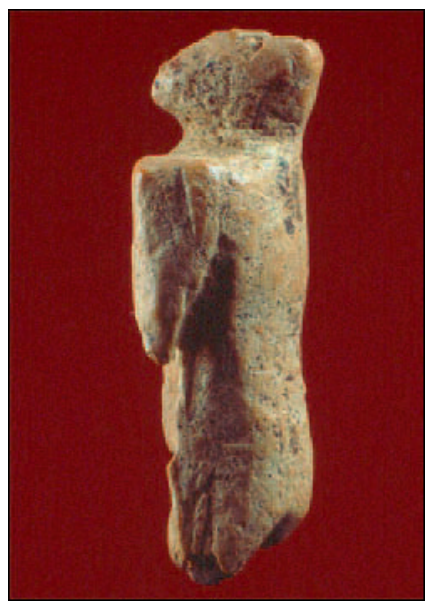

4

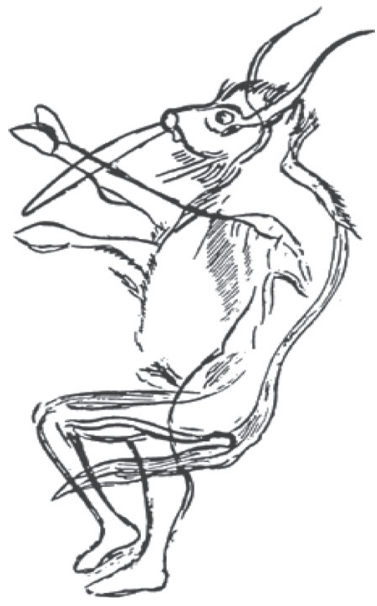

7

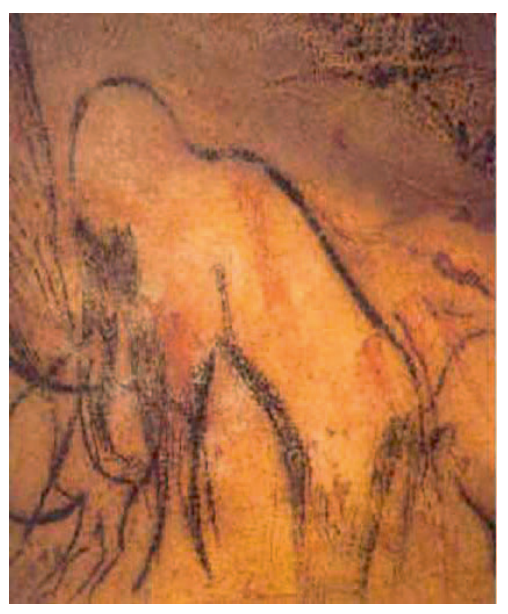

2

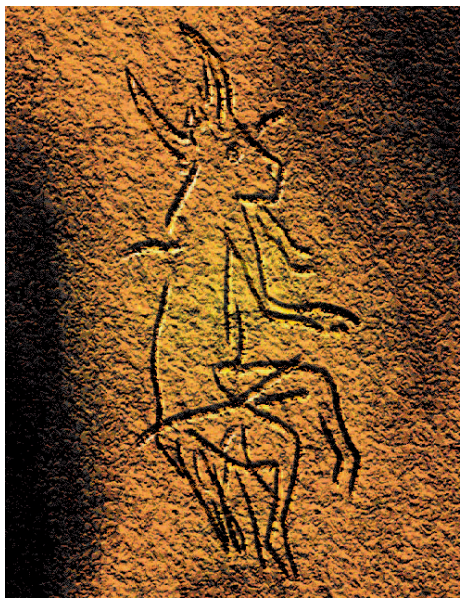

5

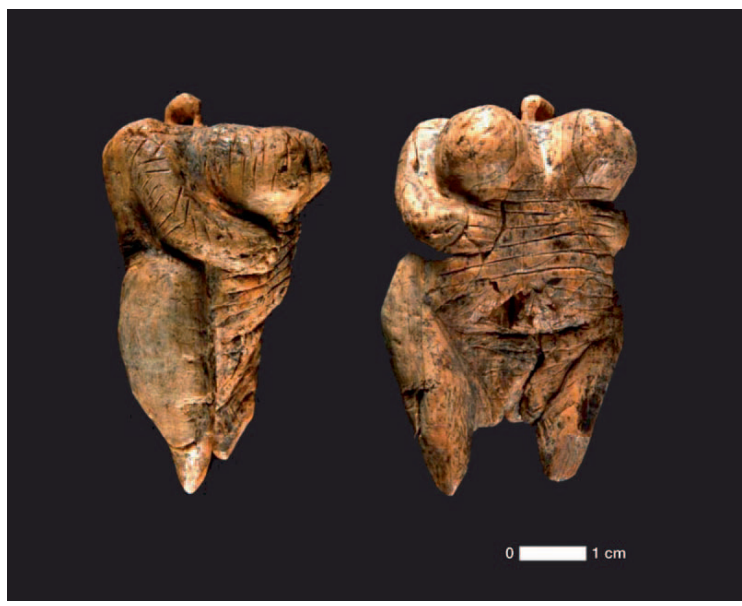

8

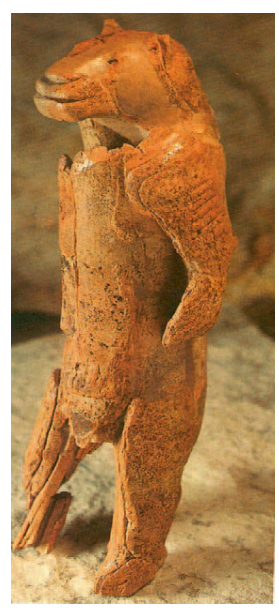

3

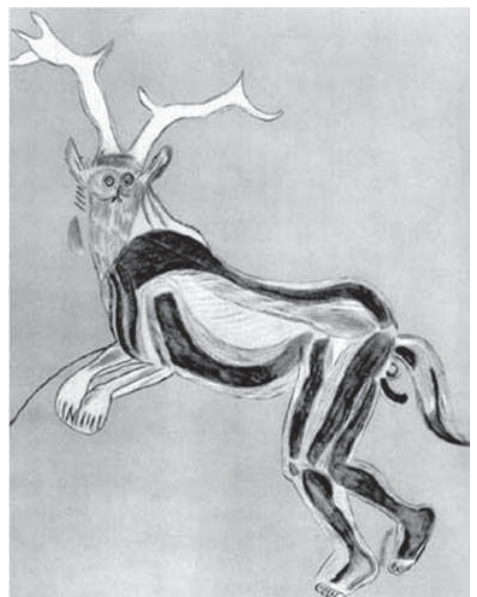

6

\ LÁmina 1. Humanos bestializados o teriántropos. 1: Chauvet; 2: Pech-Merle; 3: Höhlenstein-Stadel; 4: Hohle Fells, 5: Le Gabollou; 6 y 7: Trois-Frères; 8: Venus auriñaciense de Hohle Fells. 


\section{BIBLIOGRAFÍA}

Abramova, Z. 1995: L'Art d'Europe orientale et de la Sibérie. Jérôme MiIlon. Grenoble.

AgUiRRE, E. 2000: Evolución humana, debates actuales y vías abiertas. Discurso leído en el acto de recepción a la Real Academia de Ciencias Exactas, Fisicas y Naturales. Madrid.

Álvarez, E. 2006: Los objetos de adorno-colgantes del Paleolítico superior y del Mesolítico en la Cornisa Cantábrica y en el Valle del Ebro: una visión europea. Ed. Universidad de Salamanca (Colección Vitor, n. 195). Salamanca.

AlvargonzÁlez, D. 2005: "El problema de la verdad en las religiones del Paleolítico". En Jiménez, F., Peñalver Gómez, P. y Ujaldón Benítez, E. (coords.). Filosofía y cuerpo: debates en torno al pensamiento de Gustavo Bueno. Ediciones Libertarias/Prodhufi. Madrid: 213-243.

Álvarez MunÁrRIZ, L. 2005: "La conciencia humana". En L. Álvarez Munárriz y E. Couceiro Domínguez (coords.): La conciencia humana: perspectiva cultural. Anthropos. Barcelona.

Ardila, A., Ostrosky-Solís, F. 2008: "Desarrollo Histórico de las Funciones Ejecutivas". Revista Neuropsicología, Neuropsiquiatría y Neurociencias. Madrid, 8: 1-21.

Arrizabalaga, Á. 2006: "Lezetxiki (Arrasate, País Vasco). Nuevas preguntas a cerca de un antiguo yacimiento". En Cabrera, V., Bernardo de Quirós, F. y Maíllo, J. M. (eds.): El centenario de la cueva del Castillo: el ocaso de los Neandertales. Centro asociado de la UNED. Santoña: 291-309.

Baquero, R. 2004: Vygotsky y el aprendizaje escolar. Aique Grupo Editor. Barcelona.

BADER, O. N. 1978: Sunghir. Nauka. Moscú.

BAdER, N. O. y LAVRUSHIN, Y. A. (eds.) 1998: Upper Palaeolithic site Sungir (graves and environment). Scientific World. Moscú.

Balari, S., Benitez, A., Camps, M., Longa, V. y Lorenzo, G. 2010: "La importancia de ser moderno. Problemas de metodología en el debate sobre la cognición y la conducta de los neandertales". Ludus Vitalis XVIII: 143-170.

Balbín, R., AlcoleA, J. y GonzÁlez M. A. 2007: "Trabajos arqueológicos realizados en el conjunto prehistórico de Ardines en Ribadesella desde el año 1998". Excavaciones Arqueológicas en Asturias 19992002. 23-36. Oviedo.

Benazzl, S., Douka, K., Fornal, C., Bauer, C. C., Kullmer, O., Svoboda, J., PaP, I., Mallegni, F., Bayle, P., Coouerelle, M., Condemi, S., Ronchitelli, A., Harvati, K. y WeBER, G. W. 2011: "Early dispersal of modern humans in Europe and implications for Neanderthal behaviour". Nature 479: 525-528.

BICKERTON, D. 1994: Lenguaje y especie. Alianza. Madrid.

- 2009: Adam's Tongue: How Humans Made Language, How Language Made Humans. Hill and Wang. New York.

BISSON, M. S., TISNERAT, N. y WHITLN, R. 1996: "Radiocarbon dates from the Upper Paleolithic of Barma Grande". Current Anthropology 37: 156-162.

BoSINSKY, G. 2005: "El arte mueble paleolítico en Europa central y oriental". En J. A. Lasheras y J. González Echegaray (eds.): El significado del arte paleolítico. Santander.

BrICKER, H. M. 1995: Le Paleolithique Superieur de l'abri Pataud (Dordogne): Les Fouilles de H. L. Movius, Jr. Documents d'Archeologie Francaise. Maison des Sciences de l'Homme. Paris.

BRICKER, H. M. y MelLaRS, P. A. 1987: "Datations C-14 de l'abri Pataud (Les Eyzies, Dordogne) par le procede acélérateur-spectomètre de masse". L'Anthropologie 91: 227-234.

Broglio, A. y DALMERI G. (dir.) 2005: "Pitture paleoltiche nelle prealpi venete. Grotta di Fumane e Riparo Dalmeri". Memorie del Museo Civico di Storia Naturale di Verona. Preistoira Alpina nr. Speciale: 89-99.

Bouzouggar, A. et al. 2007: "82000-year-old shell beads from North Africa and implications for the origins of modern human behaviour". PNAS 104/24: 9964-9969.
BRUNER, J. 1984: Acción, pensamiento y lenguaje. Alianza. Madrid.

Bueno, G. 1991: "La Etología como ciencia de la Cultura". El Basilisco:3-37. Oviedo.

- 1996: El animal divino. Ensayo de una filosofía materialista de la religión. Pentalfa Ed. Oviedo.

CARbonell, E. y Mosouera, M. 2006: "The emergence of a symbolic behaviour: the sepulchral pit of Sima de los Huesos, Sierra de Atapuerca, Burgos, Spain". Comptes Rendus Palevol, 5: 155-160.

Chauvet, J. M., Brunel, E. B. y Hillaire, C. 1995: La Grotte Chauvet $\hat{a}$ Vallon Pont-d'Arc. Éditions du Seuil. Paris.

CloTtES, J. 2001: La grotte Chauvet: I'art des origines. Ed. Seuil. París.

Clottes, J., Valladas H., Cachier, H. y Arnold, M. 1992: "Des dates pour Niaux et Gargas". Bulletin de la Société préhistorique française 89 (9): 270-274.

Chauvent, J.M., Brunel-Deschamps, E., Hillaire, C., Daugas, J.P., Arnold, M., Cachier, H., Evin, J., Fortin, P., Oberlin, C., Tisnérat, N. y Valladas, H. 1995: "Les peintures paléolithiques de la grotte Chauvet-Pont d'Arc, à Vallon-Pont-d'Arc (Ardèche, France): datations directes et indirectes par la méthode du radiocarbone". C.R. Acad. Sc. 320 (Ila): 1133-40.

CONARD, N. J. 2009: "A female figurine from the basal Aurignacian of Hohle Fels Cave in southwestern Germany". Nature 459: 248-252.

Conard, N. J., Niven, L.B., Mueller, K. y Stuart, A. J. 2003: "The Chronostratigraphy of the Upper Paleolithic Deposits at Vogelherd". Mitteilungen der Gesellschaft für Urgeschichte 12: 73-86

Conard, N. J., Malina, M. y Münzel, S. C. 2009: "New flutes document the earliest musical tradition in southwestern Germany". Nature 460: 737-740.

CoolidgE, F. L. y WYNN, T. 2011: "The implications of the working memory model for the evolution of modern cognition". International Journal of Evolutionary Biology.

DAmasio, A. 2010: Y el cerebro creó al hombre. Ed. Destino. Barcelona.

Defleur, A. 1993: Les sepultures moustériennes. CNRS Edt. Paris.

DelLuc, B y Delluc, G. 1991: "L'art pariètal archaïque en Aquitaine". Supl. Gallia Prehistorique XXVIII: 28-22.

D'ERRICO, F. y StRINGER, CH. B. 2011: "Evolution, revolution or saltation scenario for the emergence of modern cultures?". Philosophical Transactions B. 366: 1060-1069.

DJINDJIAN, F., KozLOWSKI, J. y OTTE, M. 1999: Le Paléolithique supérieur en Europe. Armand Colin. Paris.

Donald, M. 1991: Origins of the Modern Mind: Three Stages in the Evolution of Culture and Cognition. Harvard University. Harvard.

Edelman, G. M. 1994: Bright Air, Brilliant Fire: On the Matter of the Mind. Penguin. Harmondsworth.

Edelman, G. M. y Tononi, G. 2000: Un Universe of Consciousness. Basic Books. New York.

Einwögerer, T., Friesinger, H., Händel, M., Neugebauer-Maresch, C., SimON, U. y TeSChleR-Nicola, M. 2009: "Upper Paleolithic infant burials". Nature 444: 285.

ELías, N. 1990: La sociedad de los individuos. Ensayos. Península / Ideas. Barcelona.

Fernández Rey, A., Adan Álvarez, G. E., Arbizu, M. y Arsuaga, J. J. 2005: "Grafismo rupestre paleolítico de la Cueva del Conde (Tuñón, Santo Adriano, Asturias)". Zephyrus. 58: 67-88.

FillmoRe, CH. 1968: The Case for Case. En E. Bach y R. T. Harms (comps.). Universals in Linguistic Theory. Holt, Rinehart and Ewinston. New York.

FORMICOLA, V. 2007: "From the Sunghir children to the Romito dwarf: Aspects of the Upper Paleolithic funerary landscape". Current Anthropology 48 (3): 446-452.

Fortea PÉReZ, J. 1990: "Abrigo de la Viña. Informe de las campañas 1980-1986". En Excavaciones arqueológicas en Asturias 1983-86. 55-68. Servicio de Publicaciones del Principado de Asturias. Oviedo.

- 1992: "Abrigo de la Viña. Informe de las campañas de 1987 a 1990". En Excavaciones arqueológicas en Asturias 1987-90. 19-28. Servicio de Publicaciones del Principado de Asturias. Oviedo. 
- 1994: "Los santuarios exteriores en el Paleolítico Cantábrico". En Chapa, T. y Menéndez, M. (ed.): Arte Paleolítico. Cumplutum 5: 203220.

- 2007: "39 edades ${ }^{14} \mathrm{C}$ AMS para el arte rupestre en Asturias". Excavaciones Arqueológicas en Asturias 1999-2002: 91-102. Oviedo.

ForTEA, J., RASILLA, J. y Rodriguez, V. 2004: "L'Art pariétal et la séquence archéologique paléolithique de la grotte de LLonín (Peñamellera Alta. Asturies. Espagne)". Préhistoire, arts et societés LIX: 7-29.

GAMBLE, C. 1984: "Regional variation in hunter-gatherer strategy in the Upper Pleistocene of Europe". En Hominid evolution and community ecology. Ed. R. Foley, Academic Press. London: 163-172.

- 1990: El poblamiento paleolítico de Europa. Editorial Crítica. Barcelona.

- 2001: Las sociedades paleolíticas de Europa. Ariel Prehistoria. Barcelona.

GARGET, R. H. 1989: "Grave Shortcomings: the evidence for Neanderthal burials". Current Anthropology 30: 157-190.

- 1999: "Middle Paleolithic Burials is not a dead issue: the view from Qafzeh, Saint-Césaire, Kebara, Amud and dederiyeh". Journal Human Evolution 37: 27-90.

GarRaldA M. D. 2008: "Les Néandertaliens: d'autres gestes envers les défunts". En: B. Vandermeersch, J.-J. Cleyet-Merle, J. Jaubert, B. Maureille y A. Turq (eds.): Première humanité, gestes funéraires des Néandertaliens. Réunion des Musées Nationaux. Paris: 42-51.

GIACOBINI, G. 2006: "En paralléle aux sepultures. Histoire des idées sur d'otres pratiques mortuaires attribuées aux Néanderthaliens". C.R. Paleovol. 5: 177-182.

GoodAL, J. 1972: Grub: The Bush Baby. Houghton Mifflin. Boston.

González Echegaray, J., Freeman, L. G. 1978: Vida y muerte en cueva Morín. Institución Cultural de Cantabria, Diputación Provincial. Santander.

GonzÁlez SAINZ, C. 1999: "Sobre la organización cronológica de las manifestaciones graficas del Paleolítico Superior. Perplejidades y algunos apuntes desde la región cantábrica". Edades. Revista de Historia 6: 123-144.

González Sainz, C. y San Miguel Llamosas, C. 2001: Las cuevas del desfiladero: Arte rupestre paleolítico en el valle del río Carranza (Cantabria-Vizcaya). Universidad de Cantabria. Santander.

HAHN, J. 1970: "Recherches sur I'Aurignacien en Europe Centrale et Orientale". L'Anthropologie 74: 195-200.

- 1987: "Aurignacian and Gravettian settlement patterns in central Europe". En Soffer 0: The Pleistocene Old World. Regional Perspectives. The Pleistocene Old World. Regional Perspectives. New York: 251-262.

- 1992: Der Hohle Fels bei Schelklingen, Alb-Donau-Kreis - Die Ausgrabung 1991. Archäologische Ausgrabungen in Baden-Württemberg: 21-23.

Hayden, B. 1992: "Competition, Labor and Complex Hunter-Gatherers". En Ernest, S., Burch, J. y Ellana I. (eds.): Key issues in HunterGatherer Research (Explorations in Anthropology): Berg Publishers. Oxford: 223-239.

Hensihlwood, CH., D'Errico, F., Vanhaeren, M., Van Niekerk, K. y JaCOBS, Z. 2004: "Middle Stone Age Shell Beads from South Africa". Science 304: 404.

HenRY-Gambier, D y White R. W. 2003: "New chrono-cultural data on the Cro-Magnon and Combe-Capelle human remains (Dordogne, France): consequences for the biocultural origins of modern humans in Europe". En Annual Meetings of the Paleoanthropology Society. Tempe. Arizona.

HERNANDO, A. 1999: "Percepción de la realidad y Prehistoria, relación entre la construcción de la identidad y la complejidad socio-económica en los grupos humanos". Trabajos de Prehistoria 56 (2): 19-35.

Higham, T., JaCobi, R., Julien, M., David, F., Basell, L., Wood, R., Davies, W. Y Bronk RAMSEY, C. 2010: "Chronology of the Grotte du Renne (France) and implications for the context of ornaments and human remains within the Châtelperronian". PNAS 10: 1073.
HODDER, I. 1991: "Interpretive archaeology and its role". American Antiquity, 56 (1): 7-18.

- 1993: "Social Cognition". En Renfrew, C et. al.: "What is Cognitive Archaeology?" Cambridge Archaeological Journal, 3 (2): 253-257.

HOFFECKER, J. F. 2011: "The early upper Paleolithic of eastern Europe reconsidered. Evolutionary". Anthropology: Issues, News, and Reviews 20: 24-39.

JeNKINS, R. 1996: Social Identity. Routledge. New York y London.

JACOBI, R. M y HIGHAM, T. F. G. 2008: "The 'Red Lady' ages gracefully: New Ultrafiltration AMS determinations from Paviland". Journal of Human Evolution 55: 898-907.

KLEIN, R. G. 2003: "Whither the Neanderthals?" Science 299: 1525-1527.

KozlowskY, J. K. 1992: L'Art de la Préhistoire en Europe orientale. CNRS Paris.

Krause, J., Fu, Q., Good, J. M., Viola, B., Shunkov, M. V., Derevianko, A. P. y PAABO, S. 2010: "The complete mitochondrial DNA genome of an unknown hominin from southern Siberia". Nature 464: 894-897.

LAMMING-EMPERAIRE, A. 1962: La signification de l'Art rupestre paléolithique. Editions Picard. Paris.

LÉvi-Strauss, C. 1964: El pensamiento salvaje. Fondo de Cultura Económica. México.

Lewis-WiLliams, D. 2005: La mente en la caverna: La conciencia y los origenes del arte. Akal, Madrid.

LEONARDI, P. 1988: "Art Paléolithique mobilier et parietal en Italie". L'Anthropologie 92: 139-202

LORBLANCHET, M. 1999: La naissance de l'Art. Genèse de l'art préhistorique. Edit. Errance. Paris.

MALAFOURIS, L. 2008: "Between brains, bodies and things: tectonoetic awareness and the extended self". Phil. Trans. R. Soc. B363: 1993-2002.

- 2010: "The brain-artefact interface (BAI): a challenge for archaeology and cultural neuroscience". SCAN 5: 264-273.

MaLmBerG, T. 1980: Human Territoriality. La Haya, Mouton.

MARINA, J. A. 1998: La selva del lenguaje. Introducción a un diccionario de los sentimientos. Anagrama. Barcelona.

MeLLARS, P. A. 2006: "Archaeology and the dispersal of modern humans in Europe: Deconstructing the Aurignacian". Evolutionary Anthropology. 15: 167-182.

MENÉNDEZ, M. 1994: "Arte rupestre y arte mueble paleolítico: Relaciones". Complutum 5: 343-355.

- 2012: "Territorialidad y territorio en los estudios Paleolíticos". En El Paleolítico Superior Cantábrico. Actas de la Primera Mesa Redonda. San Román de Cándamo (Asturias) 26-28 de abril de 2007. Publican Ediciones: 13-20.

Mithen, S. (1998): Arqueología de la mente. Crítica. Barcelona.

MoRIN, E. 1970: "Préface à la deuxième èdition". L'homme et la mort. Éditions du Seuil (Col. Point, n. ${ }^{\circ}$ 77, 9 éd.) Paris.

Morwood, M.J., GILLIS, D., SMITH, W. y KETTE, F. 2005: "Further evidence for small-bodied hominins from the Late Pleistocene of Flores, Indonesia". Nature 437: 1012-1017.

MoRA, F. 2001: El reloj de la sabiduría. Tiempos y espacios en el cerebro humano. Alianza Editorial. Madrid.

- 2002: Cómo funciona el cerebro. Alianza. Madrid.

MusSI, M., FrAYER, D. W. y MACCHIARELI, R. 1989: "Les vivants et les morts. Les sépultures du Paléolithique supérieur en Italie et leur interprétation". En Hershkovitz, I. (ed.): People and Culture in Change. BAR Intl. Series 508, 0xford: 435-458.

NoblE, W. y DAVIDSON, I. 1996: Human Evolution, Language and Mind. Cambridge University Press. Cambridge.

Palma Di Cesnola, A. 2001: "Le Paléolithique supérieur en Italie". Éditions Jérôme Millon (collection L'Homme des origines, série Préhistoire d'Europe, n. 9). Grenoble.

PeResani, M., Fiore, I., RomandinI, M. y TAglacozzo, A. 2011: "Late Neandertals and the intencional renoval of feathers as evidenced from bird bone taphonomy at Fumane Cave 44Ky Italy". PNAS 108 (10): 3888-93.

PIAGET, J. 1952: The origins of intelligence in children. Norton. New York. 
Pike, A. W. G., Hoffmann, D. L., Garcia-Diez, M., Pettim, P. B., Alcolea, J., de Balbin, R., González-Sainz, C., de las Heras, C., Lasheras, J. A., MonTES, R. y ZILHAO 2012: "U-Series Dating of Paleolithic Art in 11 Caves in Spain". Science: 1409-1413.

Powell, A., Shennan, S. y Thomas, M. G. 2009: "Late Pleistocene Demography and the Appearance of Modern Human Behavior". Science 324: 1298-1301.

Rasilla, M., Rodriguez, V., Santamaría, D. y Fortea, J. 2010: "Los grabados parietales paleolíticos del abrigo de Cueto de la Mina (Posada de Llanes, Asturias)". Munibe 61: 35-50.

Rasilla, M., Rosas, A., Cañaveras, J. C. y Lalueza-Fox, C. (eds.) 2012: La Cueva del Sidrón (Borines, Piloña, Asturias). Consejería de Cultura y Turismo. Oviedo.

REID, R.G.B. 2007: Biological Emergences. Evolution by Natural Experiment. Cambridge, MA: The MIT press. Cambridge.

RENFREW, C. 1982: Towards an Archaeology of Mind: an Inaugural Lecture delivered before the University of Cambridge. Cambridge University Press.

- 1993: "Cognitive Archaeology: Some Thoughts on the Archaeological Thought". Cambridge Archaeological Journal, 3(2): 248-250.

- 2008: "Neuroscience, evolution and the sapient paradox: the factuality of value and of the sacred". Phil. Trans. R. Soc. B 363: 2041-2047.

ReNFREW, C., BAHN, P. 2007: Arqueología: Teorías, métodos y práctica. Akal. Madrid.

RICHTER, D., WAIBLINGER, J., RINK, W. J. y WAgneR, G. A. 2000: "Thermoluminescence, Electron Spin Resonance and 14C-dating of the Late Middle and Early Upper Palaeolithic Site of Geißenklösterle Cave in Southern Germany". Jounal of Archaeological Science 27: 71-89.

RIVERA, A. 2003-2004: "La conducta simbólica humana: Nueva orientación metodológica". Espacio, Tiempo y Forma. Serie I, Prehistoria y Arqueología: 16-17.

- 2005: Arqueología cognitiva. El origen del simbolismo humano. Arco/Libros. Madrid.

- 2009: Arqueología del lenguaje. La conducta simbólica en el Paleolítico. Akal. Madrid.

- 2010: "Conducta simbólica. La muerta en el Musteriense y MSA". Zephyrus 65 (1): 39-63.

SeARLE, J. R. 2000: El misterio de la conciencia. Paidos. Barcelona.

Semino, O., PAssarino, G. y Oefner, P. J. et al. 2000: "The genetic legacy of Paleolithic Homo sapiens sapiens in extant Europeans: a Y chromosome perpective". Science 290: 1.155-9.

SHENNAN, S. 2001: "Demography and Cultural Innovation: a model and its implications for the emergence of modern human culture". Cambridge archaeological journal 11: 5-16.

Slimak, L., Svendsen, J. I., Mangerud, J., Plisson, H., Brugère, H. A. y PAVLoV, P. Y. 2011: "Late Mousterian Presistence near tha Arctic Circle". Science 332: 841-845.

StRaus, L. G. 2005: "A mosaic of change: the Middle-Upper Palaeolithic transition as viewed from New Mexico and Iberia". Quaternary International. 137: 1, p. 47-67.

TABORIN, Y. 1993: "La parure en coquillage au Paléolithique". Gallia Préhistoire, supplement 29. CNRS. Paris.

- 2004a: Langage sans parole. La parure aux temps préhistoriques. La Maison des Roches. Paris.

- 2004b: "El adorno: lenguaje del cuerpo". En Arias, P. y Ontanon, R. La materia del lenguaje prehistórico. El arte mueble paleolítico de Cantabria en su contexto. Gobierno de Cantabria: 151-160.

Tomasello, M. 2007: Los orígenes culturales de la cognición humana. Amorrortu. Buenos Aires.

TYLOR, E. 1871: Primitive Culture. New York.

VAndermeersCH, B. 1987: "Le peuplement du Poitou-Charentes au Paléolithique Inferieur et Moyen". Préhistoire du Poitou-Charentes. Problémes actuels. Edit. de CTHS: 7-15

- 2005: "Ce que nous apprenent les premieres sépultures". C.R. Palevol, 5: 161-167
Vanhaeren, M., D'Errico, F. 2006: "Aurignacian ethno-linguistic geography of Europe revealed by personal ornaments". Journal of Archaeological Science. 33: 1105-28.

VIALOU, D. 2004: La vie au temps des mammouths. Dossier pour la Science 43.

VYGoTSKY, L. V. 1979: El desarrollo de los procesos psicológicos superiores. Grijalbo. Barcelona.

Walker, M. J., Gibert, J., López, M. V., Lombardi, A. V., Pérez-Pérez, A., Zapata, J., ORTega, J., Higham, T., PIKE, A., SCHWenninger, J. L., ZILHÃO, J. y TrINKAUS, E. 2009: "Late Neanderthals in Southeastern Iberia: Sima de las Palomas del Cabezo Gordo, Murcia, Spain". PNAS 105-52: 20.631-20.636

WeLLS, S. 2002: The Journey of Man: A Genetic Odyssey. Penguin. Londres.

WHITE, R. 1993: "A technological View of Castelperronian and Aurignacian Body Ornaments in France". En V. CABRERA (ed.): El origen del hombre moderno en el suroeste de Europa. UNED. Madrid.

WYNN, T. 1981: "Intelligence of Oldowan hominids". Journal of Human Evolution 10: 529-41.

- 1985: "Piaget, stone tools, and the evolution of human intelligence". World Archaeology 17: 32-43.

WYNN, T. y CoolidgE, F. L. (2004): "The expert Neanderthal mind". Journal of Human Evolution 46: 467-487.

ZІІнÄо, J. 2007: "The Emergence of Ornaments and Art: An Archaeological Perspective on the Origins of Behavioral Modernity". Journal of Archaeological Research 5: 1-54.

ZILHÄO, J. y TrinkAus, E. (eds.) 2002: "Portrait of the Artist as a Child. The Gravettian Human Skeleton from the Abrigo do Lagar Velho and its Archeological Context". Trabalhos de Arqueologia 22: 609.

ZıเнÄо, J. et al. 2010: "Symbolic use of marine shells and mineral pigments by lberian Neandertals". PNAS 107/3: 10023-10028.

Bibliografía citada en los cuadros

Cuadro 5.

Enterramientos neandertales

AkAzAWA, T., MuHESEn, S. (eds.) 2003: "Neanderthal burials: excavations of the Dederiyeh Cave, Afrin, Syria". KW Publications Ltd. Auckland.

BAR-YOSEF, O. 1989: "Geochronology of the Levantine Middle Palaeolithic". En P. Mellars y C. Stringer, (eds.): The Human Revolution: Behavioural and Biological Perspectives on the Origins of Modern Humans. Edinburgh University Press. Edinburgh.

BINANT, P. 1991: Le prehistoire de la mort. Les premières sépultures en Europe. Errance (Colectión des Hespérides). Paris.

BonifaY, E. 2008: "Le site de Regourdou (Montignac-sur-vézère, dordogne) et le problème de la signification des sépultures néandertaliennes". Bulletin de la Société d'études et de recherches préhistoriques des Eyzies. ESEP 57: 26-32.

DÉBENATH, A. y JELINEK, A. 1998: "Nouvelles fouilles à La Quina: resultants preliminaires". Gallia Préhistoire 40: 29-74.

GrüN, R. y STRINGER, C. B. 1991: "Electron spin resonance dating and the evolution of modern humans". Archeometry 33: 153-199.

Madre-Dupouy, M. 1991: "Principaux caractères de l'enfant néanderthalien du Roc de Marsal, Dordogne (France)". L'Anthropologie 95: 523-534.

MeLLARS, P. A. 1989: "Major issues in the emergence of modern humans". Current Anthropology 30: 349-385.

Mercier, N., Valladas, H., Froget, L., Joron, J. L., Ronen, A. 2000: "Datation par la thermoluminescence de la base du gisement paleolithique de Tabun (Mont Carmel, Israel)". CR Acad Sci 330: 731-738.

OVCHINNIKOV, I. V., GotheRSTROM, A., ROMANOVA, G. P., KHARITONOV, V. M. y LIDEN, K. G. W. 2000: "Molecular analysis of Neanderthal DNA from the northern Caucasus". Nature 404: 490-493.

RAK, Y., KImBEL, W. H. y HoverS, E. 1994: "A Neandertal infant from Amud Cave, Israel". Journal of Human Evolution 26: 313-324. 
Riel-Salvatore, J. y Clark. G. A. 2001: "Grave Markers Middle and Early Upper Paleolithic Burials and the Use of Chronotypology in Contemporary Paleolithic Research". Current Anthropology 42 (4): 449478.

Semal, P., Rougier, H., Crevecoeur, I., Jungels, C., Flas, D., Hauzeur, A. Maureille, B., Germonpré, M., Bocherens, H., Pirson. S., Cammaert, L., de Clerck, N., Hambucken, A., Higham, T., Toussaint, M., Van der Plicht, J. 2009: "New data on the late Neandertals: Direct dating of the Belgian Spy fossils". Am J Phys Anthropo 138 (4): 421-428.

SkinNeR, A. R., BlackWell, B. A. B., Martín, S., ORTega, A., BLICKSTeIn, J. I. B., Golovanova, L.V., DoronicheV, V. B. 2005: "ESR dating at Mezmaiskaya Cave, Russia". Proceedings of the 6th International Symposium on ESR Dosimetry and Applications 62 (2): 219-224.

TRINKAUS, E. y ZILHAO, J. (eds.) 2002: "Portrait of the Artist as a child: the gravettian human skeleton from the Abrigo do Lagar Velho and its archeological context". En Social Implications. Trabalhos de Arqueología 22: 519-541.

Valladas, H., ReYss, L., Joron, J. I., Valladas, G., Bar-Yosef, O., VanderMEERSCH, B. 1988: "Thermoluminescence dating of Mousterian Proto-Cromagnon, remains from Israel and the origin of modern man". Nature 331: 614-616.

Cuadro 6.

Antropofagia

BINANT, P. 1991: Le prehistoire de la mort. Les premières sépultures en Europe. Colectión des Hespérides. Errance. Paris.

Defleur, A., White, T., Valensi, P., Slimak, L., Cregut-Bonnoure, E. 1999: "Neanderthal cannibalism at Moula-Guercy, Ardeche, France." Science 286: 18-19.

De LUMLEY, M-A. 1973: "Anténéandertaliens et Néandertaliens du bassin méditerranéen occidental européen". Études Quaternaires mémoire 2: 551-558.

Garralda M. D., Giacobini G., Vandermeersch B. 2005: "Neanderthal Cutmarks: Combe-Grenal and Marillac (France)". SEM Análisis 43 (2-3): 189-197.

Higham, T., Ramsey, C. B., Karavanic, I., Smith, F. H., Trinkaus, E. 2006: "Revised direct radiocarbon dating of the Vindija $G_{1}$ Upper Paleolithic Neandertals". Proc. Nat. Acad. Sci. 103: 553-557.

Hublin, J-J., Barroso Ruiz, C., Fontugne, M., Medina Lara, P., Reyss, J. 1995 "The Mousterien site of Zafarraya (Andalucia, Spain): dating and implications on the paleolithic peopling processes of Western Europe". Comptes Rendues de l'Académie de Sciences de Paris 321 , série lla: 931-937.

LE MORT, F. 1989: "Traces de décharnement sur les ossements néandertaliens, de Combe-Grenal (Dordogne)". Bulletin de la Société Préhistorique Française 86: 79-97.

Mann, A. E., Beauval, C., Costamagno, S., Bordes, J. G., Bourguignon, L., Couchoud, I., Lacrampe, Fr., Laroulandie, V., Marouet, J. Cl., Meignen, L., Texier, J. P., Vandermeersch, B., Maureille B. 2005 "Carnivore and Neandertal interactions at the Les Pradelles site (Charante, Southwest France)". Paleoanthropological Society Abstracts.

Montet-White, A. 1996: "Le Paléolithique en ancienne Yougoslavie". Série Préhistoire d'Europe, 4. Jérôme Millon (ed.). Grenoble.
Rasilla, M., Rosas, A., Cañaveras, J. C. y Lalueza-Fox, C. (eds.) 2012: La Cueva del Sidrón (Borines, Piloña, Asturias). Consejería de Cultura y Turismo. Oviedo.

Rosas, A., Martinez-Maza, C., Bastir, M., Garcia-Tabernero, A., LaluazaFox, C., Huguet, R., Ortiz, J. E., Juliá, R., Soler, V., de torres, T., Martinez, E., Cañaveras, J. C., SÁnchez-Moral, S., Cuezva, S., Lario, J., Santamaría, D., DE LA RASILLA, M., FORTEA, J. 2006: "Paleobiology and comparative morphology of a late Neandertal sample from El Sidrón, Asturias, Spain". Proceedings of the National Academy of Sciences of the United States of America 103 (51): 19266-19271.

RusSEL, M. 1987: "Mortuary practices et the Krapina Neanderthal site". American Journal of Physical Anthropology. 72: 81-397.

SChmitz, R. W., SerRe, D., Bonani, G. et al. 2002: "The Neandertal type site revisited: interdisciplinary investigations of skeletal remains from the Neander Valley, Germany". Proc. Natl. Acad. Sci. U.S.A. 99 (20): 13342-7.

Cuadro 7.

Enterramientos de HAM

Barham, L. 2000: "Bone tools". En Barham L. (ed.): The Middle Stone Age of Zambia, south central Africa. Western Academic \& Specialist Press. Bristol.

Beaumont, B., de Villiers, H., Vogel, J. 1978: "Modern man in sub-Saharan Africa prior to 49000 year bp: a review and evaluation with particular reference to Border Cave. South African". Journal of Science 74: 409-419.

DART, R. A. y del GRANDE, N. 1931: "The ancient iron smelting cavern at Mumbwa." Transactions of the Royal Society of South Africa. 19 (4): 379-427.

GRÜN, R. y STRINGER, C. B. 1991: "Electron spin resonance dating and the evolution of modern humans". Archeometry, 33: 153-199.

MCBREARTY, S., BROokS, A. 2000: "The revolution that wasn't: a new interpretation of the origin of modern human behaviour". Journal of Human Evolution 39: 453-563.

Mercier, N., Valladas, H., Bar-Yosef, O., Vandermeersch, B., Stringer, C. y JORON, J. L. 1993: "Thermoluminescence dates from the Mousterian burial site of es-Skhul, Mt Carmel". J. Archaeol. Sci. 20: 169-174.

Riel-Salvatore, J. y Clark. G. A. 2001: "Grave Markers Middle and Early Upper Paleolithic Burials and the Use of Chronotypology in Contemporary Paleolithic Research". Current Anthropology 42 (4): 449-478.

SILLEN, A., MoRRIS, A. 1996: "Diagenesis of bone from Border Cave: implications for the age of the Border Cave hominids". Journal of Human Evolution 31: 499-506.

TrinkAUS, E. y ZILHAO, J. (eds.) 2002: "Portrait of the Artist as a child: the gravettian human skeleton from the Abrigo do Lagar Velho and its archeological context". En Social Implications. Trabalhos de Arqueología 22: 519-541.

Valladas, H., ReYss, L., Joron, J. I., Valladas, G., Bar-Yosef, O., VanderMEERSCH, B. 1988: "Thermoluminescence dating of Mousterian Proto-Cromagnon, remains from Israel and the origin of modern man". Nature 331: 614-616.

Vermeersch, P. M., Paulissen, E., Stokes, S., Charler, C., Van Peer, P., StRINGER, C., LINDSAY, W. 1998: "A Middle Palaeolithic burial of a modern human at Taramsa Hill, Egypt". Antiquity 72: 475-484. 
